\title{
Authority, reputation, and the roles of Jeanne de Penthièvre in Book I of Froissart's Chroniques
}

Journal of Medieval History (forthcoming 2019: accepted manuscript)

Erika Graham-Goering

Department of History, Ghent University, Ghent, Belgium

Abstract: This article examines how a medieval noblewoman's positive reputation could be framed through different aspects of seigneurial power using a case study of Jeanne de Penthièvre and her war for the duchy of Brittany. Froissart wrote about Jeanne in the three main redactions of the first book of his Chroniques. However, he focused in the Amiens manuscript on her position as an heiress and the object of her followers' loyalty, while the B text largely reduced her prominence but planted the seeds for the active military role Jeanne assumed in the Rome redaction. Such changes did not move strictly between more- or lessaccurate reports, but engaged with different tropes that had also featured in the official portrayals of Jeanne during her lifetime. These parallel constructions of reputation reveal a plasticity to models of lordly authority even in rhetorical contexts more usually associated with formulaic and conventional representations of elite society.

Article History: Received 16 May 2018. Accepted 5 July 2018.

Keywords: Froissart, chronicle, reputation, rhetoric, Brittany, Jeanne de Penthievre, medieval women, lordship 
Rehabilitating the reputations of politically-active medieval women has meant that, in the past few decades, a growing body of scholarship has turned a much-needed critical eye to the process by which social mores, political interests, and iconic narratives could combine to create the 'black legends' that frequently transformed more-or-less typical noblewomen, and especially queens, into immoral caricatures. For instance, Rachel Gibbons has argued that the villainous portrait of Charles VI's wife Isabeau de Bavière (1371-1435), long considered a profligate queen, inattentive mother, and faithless spouse, developed in two phases: around 1405, texts such as the chronicle of Michel Pintoin and Le Songe Véritable, which criticized the French government as a whole, also condemned the conduct of the queen; but Isabeau's alleged promiscuity was the product only of later texts and was, moreover, not directly influenced by the infamous treaty of Troyes (1420). ${ }^{1}$ Similarly, Anne-Hélène Allirot has identified three main themes in the late medieval censure of the first Valois queen, Jeanne de Bourgogne (d.1349): that, through gluttony, she failed in her wifely duties; that she was a cruel, vengeful queen possibly possessed of occult powers; and that she was a monstrous woman for wishing to act as a ruler. Each of these threads evolved in two phases as different writers developed new attacks based on their strategic interests (during Jeanne's life) or elaborated on those found in earlier texts (after her death). ${ }^{2}$ These and many other such analyses have foregrounded close attention to the sources, especially chronicles, that were responsible for creating or at least circulating the mala fama, assessing the degree to which their accounts can be corroborated with historical events and with other contemporary records, as well as the stereotypes that provided easy reference points in developing a darker image. ${ }^{3}$ The process of building a neutral or even

\footnotetext{
* This work was supported by the European Research Council under Grant number 677502 (PI: Frederik Buylaert (Ghent University); Co-PI: Justine Firnhaber-Baker (University of St Andrews)); by the University of York; and by the Society for the Study of French History. I would like to thank Godfried Croenen, Claudia Wittig, and the anonymous reviewers for their generous comments on drafts of this article, and Craig Taylor, Mark Ormrod, Graeme Small, and Kristin Bourassa for their valuable feedback on earlier versions of this research.

${ }^{1}$ Rachel Gibbons, "Isabeau of Bavaria, Queen of France (1385-1422): The Creation of an Historical Villainess," Transactions of the Royal Historical Society 6 (1996): 51-73. Tracy Adams, The Life and Afterlife of Isabeau of Bavaria (Baltimore, 2010), 38-72, has more recently undertaken a similar study in greater detail.

2 Anne-Hélène Allirot, "La male royne boiteuse: Jeanne de Bourgogne," in Royautés imaginaires, ed. Colette Beaune and Henri Bresc (Turnhout, 2005), 119-33; cf. Aline Vallée-Karcher, "Jeanne de Bourgogne, épouse de Philippe VI de Valois: Une reine maudite?" Bibliothèque de l'école des chartes 138 (1980): 94-96.

${ }^{3}$ A brief selection of recent studies include Isabelle Heullant-Donat and Franck Collard, "Deux autres Jeanne...," in Une histoire pour un royaume, XIIe-XVe siècle: Actes du colloque Corpus Regni, organisé en hommage à Colette Beaune, ed. Anne-Hélène Allirot (Paris, 2010), 310-332; Ralph V. Turner, "Eleanor of Aquitaine, Twelfth-Century English Chroniclers and her 'Black Legend'," Nottingham Medieval Studies 52 (2008): 17-42; Lois L. Huneycutt, "The Creation of a Crone: The Historical Reputation of Adelaide of Maurienne," in Capetian Women, ed. Kathleen Nolan (New York, 2003), 27-43. The essays collected in Zita Eva Rohr and Lisa Benz, eds., Queenship, Gender, and Reputation in the Medieval and Early Modern West, 1060-1600 (New York, 2016), offer some new perspectives on the
} 
positive reputation, however, has tended not to be the focus of such detailed textual scrutiny, even though such reports were not necessarily more accurate or any less deliberately constructed - or alternatively, more generic and so less significant. A source-critical approach to the construction of bona fama allows us to better understand the contextual appeal of a variety of concurrent social standards for the exercise of lordly power, and the numerous tools which existed to codify and communicate them across different texts. ${ }^{4}$

This type of analysis is especially fruitful with regards to the most influential historiographer of the late Middle Ages, Jean Froissart (1337-after 1404). There have been two primary axes along which scholars have evaluated the usefulness of his Chroniques as a historical source. Its authority as a factual record came under fire from the later nineteenth century, as its evidence regarding various events was compared with that gleaned from administrative documents, legal records, and other vestiges of the medieval aristocratic world. ${ }^{5}$ Accordingly, more recent historians have focused on how the truthfulness that assumed such rhetorical significance in historiographical works of this sort lay less in facts than in 'ne pas transmettre un écho trompeur, mensonger, des bruits d'alentour: la fidélité de la reproduction est tout ce que l'on attend de sa bonne foi', even if these reports of contemporary rumour were contradictory or simply wrong. ${ }^{6}$ This revised understanding of the chronicle as a window onto the 'mental and social dimensions' of his noble audience has encouraged the study of Froissart's use and transmission of oral reports and personal interviews: sources which conveyed the 'talk'

creation of reputation, although the predominant focus remains on 'reputations created by critical responses to the disruption of social norms' ( $\mathrm{xxx}$ ) and other negative images. Note, too, that issues of (re)evaluating reputation also apply to male political figures: see, for instance, Gwilym Dodd and Anthony Musson, eds., introduction to The Reign of Edward II: New Perspectives (York, 2006), 1-3, and the essays of W. M. Ormrod, "The Sexualities of Edward II," 22-47, and Ian Mortimer, "Sermons of Sodomy: A Reconsideration of Edward II's Sodomitical Reputation," 48-60, in that collection.

4 On the parallel positive and negative implications inherent to the term fama, see Thelma Fenster and Daniel Lord Small, eds., introduction to Fama: The Politics of Talk and Reputation in Medieval Europe (Ithaca, NY, 2003$), 2$.

${ }^{5}$ With regards to the Breton affairs which will concern us here, the attack was led by François Plaine, "De l'autorité de Froissard comme historien des guerres de Bretagne au XIVe siècle, 1341-1364," Revue de Bretagne et de Vendee 29 (1871): 5-32, 119-36, though Froissart's reputation was vigorously defended by the eminent Arthur le Moyne de la Borderie, Histoire de Bretagne (Rennes, 1896-1914).

${ }^{6}$ Jean Froissart, Chroniques, ed. Siméon Luce et al. (Paris, 1869-1975), 1:cviii-ix (hereafter cited as B); cf. Jean Le Bel, Chronique, ed. Jules Viard and Eugène Déprez (Paris, 1904), 1:xxiv, 1-2 (hereafter cited as Le Bel); Nicole Chareyron, Jean Le Bel: Le maître de Froissart, grand imagier de la Guerre de Cent Ans (Brussels, 1996), 58-60; Peter Ainsworth, Jean Froissart and the Fabric of History: Truth, Myth, and Fiction in the Chroniques (Oxford, 1990), 6, 23; Zrinka Stahuljak, "Neutrality Affects: Froissart and the Practice of Historiographical Authorship," in The Medieval Author in Medieval French Literature, ed. Virginie Greene (New York, 2006), 139; Bernard Guenée, "Y a-t-il une historiographie médiévale?" Revue Historique 524 (1977): 261-75; Bernard Guenée, Histoire et culture historique dans l’Occident médiéval (Paris, 1980), 350-54. 
which sits at the centre of modern studies of reputation. ${ }^{7}$ Froissart as the recorder of reputation, however, is indissociable from Froissart as the arbiter of reputation, for while it is easy to refer to the Chroniques as a single entity, Froissart in fact repeatedly revisited his account over the course of his lengthy career. In particular, the multiple substantive revisions of the first and longest of his four books reflected alternative narrative possibilities more than they did the latest rumours: Froissart chose what was to be remembered.

The size and complexity of Froissart's Chroniques makes the issue of how he constructed reputations more amenable to detailed dissection after the fashion of George Diller's classic microlectures. ${ }^{8}$ I will use Froissart's portrayal of Jeanne de Penthièvre (d.1384), duchess of Brittany from 1341 to 1364 , as a case study in how he developed different aspects of a single role to a greater or lesser extent across the Amiens, $\mathrm{B}$, and Rome redactions of the text. ${ }^{9}$ This process in Jeanne's case centred around interpreting three key points: Jeanne's inheritance, her relationship with the barons of Brittany, and her contributions to the war of succession fought on her behalf. By varying his emphasis and using different words and even scenes to characterize these elements, Froissart continually reinvented Jeanne's role as heiress, wife, mother, and duchess, without necessarily achieving a single portrait or consistent understanding of her role. I argue that there was no definitive view towards which he could work: almost all of these were aspects of the formal representation of her role which Jeanne had already promulgated during her lifetime, as seen in the administrative and legal documents surviving from her rule, because they constituted categories of action, interaction, and status that were equally well-recognized and authoritative in fourteenth-century political society and its discourse.

\footnotetext{
${ }^{7}$ J. J. N. Palmer, ed., introduction to Froissart: Historian (Woodbridge, 1981), 5; Pierre Tucoo-Chala, "Froissart dans le Midi Pyrenéen," in ibid., 118-31; Charles T. Wood, "Froissart, Personal Testimony, and the Peasants' Revolt of 1381," in Froissart Across the Genres, ed. Donald Maddox and Sara Sturm-Maddox (Gainsville, FL, 1998), 40-49; Peter Ainsworth, "Contemporary and 'Eyewitness' History," in Historiography in the Middle Ages, ed. Deborah Mauskopf Deliyannis (Leiden, 2003), 249-276; Guenée, Culture historique, 78-85. For an overview of the impact of spoken report in the Middle Ages, see the essays in Fenster and Small, eds., Fama.

${ }^{8}$ George T. Diller, Attitudes chevaleresques et réalités politiques chez Froissart: Microlectures du premier livre des Chroniques (Geneva, 1984).

${ }^{9}$ Jean Froissart, Chroniques: Livre I, le manuscrit d'Amiens, ed. George T. Diller (Geneva, 1991-1998) (hereafter cited as Amiens); Jean Froissart, Chroniques: Dernière rédaction du premier livre, édition du manuscrit de Rome Reg. lat. 869, ed. George T. Diller (Geneva, 1972) (hereafter cited as Rome). Although Katrin E. Sjursen, "The War of the Two Jeannes: Rulership in the Fourteenth Century," Medieval Feminist Forum 51 (2015): 4-40, touches briefly on this textual variation with regards to Jeanne's role, the brevity of her survey does not allow for an analysis of its significance; her consideration of Jeanne de Flandre in the chronicle tradition is more in-depth. For a survey of how key moments of the Breton war were reworked across the different redactions, see Michael Jones, "The Breton Civil War," in Froissart: Historian, ed. J. J. N. Palmer (Woodbridge, 1981), 64-81.
} 


\section{A case study in political authority and authoritative texts}

Jeanne de Penthièvre's role as a political player was defined, both in life and in the Chroniques, by what is now known as the Breton War of Succession. An overview of the conflict alongside an outline of the textual history of the different authorial redactions of Book I of the Chroniques highlights Froissart's engagement with Jeanne's influence at pivotal moments in the war. His attention to her stands out from the rest of the late medieval chronicle tradition, as we will see; but his depiction of her position had much in common with the characterizations of Jeanne's status in her own official documents. These texts are linked by the act of defining Jeanne's reputation, a practice that lent their subject authority through reference to recognizable social dynamics.

Froissart's account of 'le grant matère et hystore de Bretagne' falls mostly within the first book of his Chroniques, covering the years 1325 to 1378 (or 1380). ${ }^{10}$ The war to which he referred occupied nearly half that period: the succession of Duke Jean III of Brittany (d.1341) took some twenty-four years to resolve, and its direct ramifications extended until the late fifteenth century. Initially, the dispute unfolded in the courtroom: Jeanne de Penthièvre, the childless duke's niece and presumptive heir in the years preceding his death, and Jean de Montfort, Jean III's half-brother, both presented the legal evidence for their claim before the parlement of King Philip VI. ${ }^{11}$ But Philip's decision in the arrêt of Conflans to accept Jeanne's claim through the homage of her husband Charles de Blois (Philip's nephew), far from resolving the issue, opened a new phase of open warfare when Jean de Montfort turned to Edward III of England for support. ${ }^{12}$ Although Jean himself died of illness only a few years later in 1345, the English forces and administration were sufficient to carry on the fight in the name of his young son. Likewise, although Charles was captured at the battle of La Roche-Derrien in 1347 and held in England until 1356, Jeanne de Penthièvre and the armies sent from France continued to defend her cause. The war ended only following Charles de Blois' death at the battle of Auray on 29 September 1364, when King Charles V urged Jeanne to reconcile with her cousin,

\footnotetext{
${ }^{10} B$, 2:86. See also Diller's convincing hypothesis (Amiens, 1:xx-xxiii) that it originally included the first hundred sections of 'Book II' or, according to Croenen, the entirety of the second book, at least in the B version: Godfried Croenen, "Jean Froissart, Chronicles [Amiens Version], [Abridged Version], $[B / C$ Version]," in The Battle of Crecy: $A$ Casebook, ed. Michael Livingston and Kelly De Vries (Liverpool, 2015), 408 (note 7).

${ }^{11}$ Erika Graham-Goering, Michael Jones, and Bertrand Yeurc'h, eds., 1341: Documents concernant le débat sur la succession ducale et le début de la guerre civile dans le duché de Bretagne (Rennes, forthcoming 2019) (hereafter cited as Débat). 127 September 1341: Hyacinthe Morice, ed., Mémoires pour servir de prenves à l'Histoire ecclésiastique et civile de Bretagne (Paris, 1742), 1421-24.
} 
who became Duke Jean IV (d.1399) after the first treaty of Guérande of 12 April 1365.

These events were recounted in whole or in part by Froissart in each of his three main redactions of Book I, represented by what are commonly termed the Amiens manuscript, the B version, and the Rome manuscript. ${ }^{13}$ The Rome manuscript, written no earlier than 1404, represents the latest and most innovative text, though it unfortunately survives only in a damaged copy whose narrative breaks off in $1350 .{ }^{14}$ The order and dating of the other two redactions have been much more controversial, but the sequence proposed by Diller and modified by Godfried Croenen seems most plausible: Amiens (1384-91) - B (1390s) - Rome (1404-15). ${ }^{15}$ In addition, an 'abridged' version written just after Amiens was evidently a distinct redaction rather than a literal abridgement of another text; if its compressed structure limits direct comparison with the other redactions, it can round out our analysis of certain key moments. ${ }^{16}$ All versions post-date the Breton War of Succession by some two decades or more, and together were about as long in their composition. This having been said, John Palmer has convincingly argued that it would be wrong to view each version as an 'improvement' on the last. ${ }^{17}$ Rather, all three redactions were composed with a good deal of independence from one another. ${ }^{18}$

Unsurprisingly, the multiple versions do not offer the same story of the events in

\footnotetext{
${ }^{13}$ Peter Ainsworth, "Jean Froissart: Chronicler, Poet and Writer," in The Online Froissart, ed. Peter Ainsworth and Godfried Croenen, v. 1.5 (Sheffield, 2013), http://www.hrionline.ac.uk/onlinefroissart/apparatus.jsp?type= intros\& intro=f.intros.PFA-Froissart. Luce's scheme identified also an 'A' version which was closely related to the B text but much more widely-copied in the Middle Ages (B, 1:xxxiv-xxxix); however, J. J. N. Palmer, "Book I (1325-78) and its Sources," in Froissart: Historian, ed. J. J. N. Palmer (Woodbridge, 1981), 9, and Croenen, "Chronicles," 407 (note 5), have more recently argued that, in its extant form, this was not wholly Froissart's own composition. For this reason, and because it was largely similar to the B text for the sections relevant here, I will not examine it separately. A later ' $\mathrm{C}$ ' version introduced some modifications to the text, but not on a scale which concerns us.

${ }^{14}$ Godfried Croenen, "La Guerre en Normandie au XIVe siècle et le problème de l'évolution textuelle des Chroniques de Jean Froissart," in La guerre en Normandie (XIe-XVe siècle), ed. Anne Curry and Véronique Gazeau (Caen, 2018), 111-47. This slightly advances the terminus post quem for this version from the traditional dating of c. 1400: Rome, 11 .

${ }^{15}$ This debate has lasted more than a century; for its main outlines see, successively, the arguments made in Jean Froissart, Euvres de Froissart: Chroniques, ed. J.-B.-M.-C. Kervyn de Lettenhove (Brussels, 1867-1877), 1.2:27-79, 136-40, 156-69; B, 1:vii-lxxxiii; and Palmer, "Book I," 12, 18-20. Diller's more recent analysis is based on internal evidence, and although he reserved some doubts, Croenen's comments help present a strong case for this chronology: Amiens, 1:xix, xxii-iii; Jean Froissart, Chroniques: Livre I (première partie, 1325-1350) et Livre II: Rédaction du manuscrit de New York, Pierpont Morgan Library M.804, ed. George T. Diller and Peter F. Ainsworth (Paris, 2001), 66-67; Croenen, "Chronicles," 396-97.

${ }^{16}$ Froissart, Euvres, ed. Kervyn de Lettenhove, vol. 17 (Brussels, 1872) (hereafter cited as Abridgement). It was completed by 1391 .

${ }^{17}$ Palmer, "Book I," 24.

${ }^{18}$ Cf. George T. Diller, "Froissart: Patrons and Texts," in Froissart: Historian, ed. J. J. N. Palmer (Woodbridge, 1981), 148.
} 
Brittany. The B redaction remained most closely aligned with the account of Jean Le Bel (c.1290-1370), while Amiens and Rome showed greater innovation. The attachment to Le Bel's work was responsible for many of the errors in Froissart's account of the war's early years. ${ }^{19}$ But Froissart's portrayals of the role of Jeanne de Penthièvre after 1341 were entirely his own: his description of Jeanne's actions following Charles' capture in 1347 was unparalleled in the work of his precursor, as were her actions in the final years of the war (Le Bel's narrative having ended in 1361)..$^{20}$ She was a character in Froissart in a way she had not been before (and was rarely again), which offers us an unusual opportunity to closely examine the development of a reputation within a single author's work..$^{21}$

Jeanne's role in Froissart's chronicle has, however, been accepted largely at face valueeven when certain red flags might have prompted a closer scrutiny of the variant texts. To broach, briefly, the very issue of negative reputations, later historiography of the Breton war has embraced the idea that the Chroniques blamed Jeanne for the disaster at Auray. ${ }^{22}$ Pierre Le Baud and Alain Bouchart, the major late medieval Breton writers, reported 'according to Froissart' that Charles was naturally inclined to make peace, but he was 'so swayed (sollicité) by his wife and the knights on his side' that he kept his promise to accept no compromise. ${ }^{23}$ But while the authority of 'Froissart' guaranteed this story a long afterlife, these lines figured in neither the B nor Amiens accounts. ${ }^{24}$ Rather, four early-fifteenth-century manuscripts of the chronicle featured certain non-authorial interpolations, including this extension of the scene

\footnotetext{
19 Jones, "Breton Civil War," 67; Chareyron, Le Bel, 130.

${ }^{20}$ Le Bel, 2:149; B, 4:43, 6:151-52; Rome, 817-18; Amiens, 3:333-34.

${ }^{21}$ Most medieval historiography of the Breton war was written in the service of the Montfortists or by other hostile writers: Cuvelier (1380s), Guillaume de Saint-André (writing c.1384), Hervé le Grant (1394-c.1416), Jean de Saint-Paul (c.1475), Pierre Le Baud (1480-1505), Alain Bouchart (published 1514)...

22 François Plaine, "Jeanne de Penthièvre, duchesse de Bretagne, et Jeanne de Flandre, comtesse de Montfort: Étude biographique et critique," Mémoires de la Société archéologique et historique des Côtes-du-Nord 6 (1874): 1-47, criticizes the blackening of Jeanne's reputation, though he does not adopt a focused textual approach.

23 Pierre Le Baud, Histoire de Bretagne, avec les chroniques des maisons de Vitré et de Laval, ed. C. d'Hosier (Paris, 1638), 323-24; cf. Alain Bouchart, Les grandes croniques de Bretaigne, ed. Marie-Louise Auger, Gustave Jeanneau, and Bernard Guenée (Paris, 1998), 2:84, and B, 6:327.

${ }^{24}$ See the complete B passage below, page 8, and Amiens, 3:407. I focus here on the most important medieval examples, though the Benedictine antiquarians who dominated Breton historiography in the eighteenth century helped carry the theme forward: see esp. Gui Alexis Lobineau, Histoire de Bretagne (Paris, 1707), 1:370. The influence of this view is such that even authors who did not directly accuse Jeanne (such as Saint-André and d'Argentré) are sometimes perceived as having done so: see the table in Laurence Moal, Auray 1364: Un combat pour la Bretagne (Rennes, 2012), 47 (cf. Guillaume de Saint-André, Chronique de l'État Breton, ed. Jean-Michel Cauneau and Dominique Philippe (Rennes, 2005), 1. 1174-75; Bertrand d'Argentré, L'histoire de Bretaigne (Rennes, 1583), 486). For modern discussions, see Jones, "Breton Civil War," 70; Jean-Christophe Cassard, La Guerre de Succession de Bretagne (Spézet, 2006), 16. On the general programs of the pre-modern historiographers, see the essays in Noël-Yves Tonnerre, ed., Chroniqueurs et historiens de la Bretagne du Moyen Âge au milieu du XXe siècle (Rennes, 2001).
} 
before Auray. ${ }^{25}$ Such revision, of course, was all the simpler because of the real variations within Froissart's own work.

In light of this textual complexity, we must consider carefully what reputation means in this context, for the most usual sense, and one which had legal weight in this period, was 'that which is commonly said, held, and told'. ${ }^{26}$ There may be traces of this in Froissart's work: he himself went to Brittany in 1366, and his oral informants included the former Penthièvre partisan Evain Charruel in 1373-74 and one of Charles de Blois' doctors, Guillaume de SaintMesmin, in 1388. ${ }^{27}$ However, given that these points of contact all occurred before or during the composition of the earliest redaction, Froissart clearly did not respond to each new piece of information in turn when revising his narrative. Rather, the distinctive portrayals he brought to the fore in each version constituted an interpretive act, and the chronicle was a source for, rather than a simple reflection of, Jeanne's reputation. ${ }^{28}$ Froissart assimilated the facts of Jeanne's life and her exercise of power to other recognized social norms in order to produce narratives appealing to a broadly-defined aristocratic audience (who might then say, hear, and tell...). ${ }^{29}$

Moreover, this is fundamentally the same process that went into the rhetoric of the official letters produced in Jeanne's lifetime, of which nearly 200 survive: some were quite elaborate, but even simpler documents represented Jeanne's public persona and voice, using formulaic standards and recognizable points of reference to communicate clearly the scope and

\footnotetext{
${ }^{25} B, 1$ :xxxiv, xxxvii; Luce classes these among the exemplars of the ' $\mathrm{A}$ ' text. This passage made it into an early printed edition of the Chroniques: Jean Froissart, Le Premier Volume de Froissart, ed. Antoine Vérard (Paris, 1499), 1:f. 165v. In fact, the tradition seems to have originated specifically with the notoriously misogynistic writer Guvelier: Jean-Claude Faucon, ed., La chanson de Bertrand du Guesclin de Cuvelier (Toulouse, 1990).

26 'Illud quod communiter dicitur, tenetur, et narratur', Antoine de Sérent, ed., Monuments du procès de canonisation du bienheureux Charles de Blois, duc de Bretagne, 1320-1364 (Saint-Brieuc, 1921), 143-44, and similar formulations throughout, offer an example from Jeanne's career. For a more in-depth study of the medieval concepts of reputation, see Bernard Guenée, Du Guesclin et Froissart: La fabrication de la renommée (Paris, 2008), esp. 35-36.

${ }_{27}$ B, 1.1:318, 4:115; Jones, "Breton Civil War," 73-74; Ernest Wickersheimer, Dictionnaire biographique des médecins en France au Moyen Age (Geneva, 1979), 264; Michael Jones, "Ancenis, Froissart and the Beginnings of the War of Succession in Brittany (1341)," in Between France and England: Politics, Power and Society in Late Medieval Brittany (1999; Aldershot, 2003), 3. Moreover, Charles' nephew Guy de Blois was one of Froissart's patrons: see Godfried Croenen, "Froissart et ses mécènes: Quelques problèmes biographiques," in Froissart dans sa forge: Actes du colloque réuni à Paris du 4 au 6 Novembre 2004, par M. Michel Zink, ed. Odile Bombarde (Paris, 2006), 15-20; B, 1:liii-iv; Diana B. Tyson, "French Vernacular History Writers and Their Patrons in the Fourteenth Century," Medievalia et Humanistica, New Series 14 (1986): 103-24; Ainsworth, "Writer."

${ }^{28}$ Guenée, Renommée, 67, speaks usefully of the 'artisan de renommée', particularly as applied to medieval historiographers (and see his wider discussion on this theme, 61-73).

${ }^{29}$ Froissart's French readership was primarily comital, at least until the mid-fifteenth century: Laurence HarfLancner, "Image and Propaganda: The Illustration of Book 1 of Froissart's Chroniques," in Froissart Across the Genres, ed. Donald Maddox and Sara Sturm-Maddox (Gainesville, FL, 1998), 235.
} 
nature of her authority to others..$^{30}$ These administrative records thus offer a sort of cross-check for themes developed by Froissart, as the following example demonstrates. In a moving scene, Froissart imagined the moment in 1364 where Charles left his wife to ride to the fateful battle of Auray:

At his departure and leave-taking, milady the wife of lord Charles de Blois said to her husband, with milord Bertrand du Guesclin and several barons of Brittany present, 'Milord, you are going to defend and preserve my inheritance and yours, for what is mine is yours. In this lord Jean de Montfort impedes us, and has long impeded us, wrongly and without cause: God knows, and these barons of Brittany, that I am the rightful heiress. So I pray you dearly that you commit to no arrangement, accord, or treaty by which the whole of the duchy does not remain ours'. And her husband promised her this. And so he left, with all the barons and lords who were there, and took their leave of the lady whom they held as duchess. ${ }^{31}$

The congié or leave-taking was a typical courtly practice often reflected in literature, and this scene might easily be taken for one of the recurring set-pieces and tropes that can leave an impression of Froissart as a largely complacent choreographer of chivalry and royalty, servile in his almost liturgical portrayal of the rituals of chivalrous society and of the achievements of the eminent'. ${ }^{32}$ This stylization, however, concisely conveyed certain important points which were, moreover, not new to Jeanne's public image. More than forty years earlier, in 1343, Jeanne

${ }^{30}$ Cf. Els De Paermentier, "Instruments of Administrative Identity and Princely Power: Repetitive Protocol and Dispositive Text Formulas in the Charters of the Count(esse)s of Flanders and Hainaut (1191-1244)," in La Formule au Moyen Age II: Actes du colloque international de Nancy et Metz, 7-9 juin 2012, ed. Isabelle Draelants and Christelle Balouzat-Loubet (Turnhout, 2015); Benoît-Michel Tock, introduction to Les actes comme expression du pouvoir au haut Moyen Âge, ed. Marie-José Gasse-Grandjean and Benoît-Michel Tock (Turnhout, 2003), 11; Olivier Guyotjeannin, Jacques Pycke, and Benoit-Michel Tock, Diplomatique médiévale, 3rd ed., L'atelier du médiéviste 2 (Turnhout, 2006), 102; Hagen Keller, "The Privilege in the Public Interaction of the Exercise of Power: Forms of Symbolic Communication Beyond the Text," in Medieval Legal Process: Physical, Spoken and Written Performance in the Middle Ages, ed. Marco Mostert and P. S. Barnwell (Turnhout, 2011), 77; Herwig Wolfram, "Political Theory and Narrative in Charters," Viator 26 (1995): 42. A revised and supplemented edition of Jeanne's acts has recently become available online: Michael Jones, ed., Recueil des actes de Charles de Blois et feanne de Penthièvre, duc et duchesse de Bretagne (1341-1364), suivi des actes de Jeanne de Penthièvre (1364-1384) (1996; repr., Rennes, 2016), http://books.openedition.org/pur/28420 (hereafter cited as RACf).

31 'Au departement et au congiet prendre, madame la femme à monsigneur Charle de Blois dist à son mari, present monsigneur Bertran de Claiekin et aucuns barons de Bretagne, 'Monsigneur, vous en alés deffendre et garder mon hiretage et le vostre, car ce qui est mien est vostre, lequel messires Jehans de Montfort nous empeece et a empeechiet un grant temps à tort et sans cause: ce set Dieus et li baron de Bretagne qui chi sont comment j'en sui droite hiretière. Si vous pri chierement que, sus nulle ordenance ne composition ne trettié d'acort ne voeilliés descendre que li corps de la ducé ne nous demeure'. Et ses maris li eut en couvent. Adonc se parti, et se partirent tout li baron et li signeur qui là estoient, et prisent congiet à leur dame qu'il tenoient pour duçoise', $B, 6$ :151-52; cf. Amiens, 3:333-34.

32 Peter Ainsworth, "Froissardian Perspectives on Late-Fourteenth-Century Society," in Orders and Hierarchies in Late Medieval and Renaissance Europe, ed. Jeffrey Denton (Basingstoke, 1999), 62, emphasis original. On congié, see David Burnley, Courtliness and Literature in Medieval England (London, 1998), 57-58. 
had transferred a large portion of her lands in the duchy to her husband Charles de Blois. The official letters declaring the donation - among the most detailed documents ever issued by Jeanne - laid out the motivation for this exchange in a short narratio or preamble:

Let all know that, since I was left young and orphaned after the death of my dearest lord and father milord Guy de Bretagne, my good and loyal friends, considering and foreseeing the developments and proceedings which could come to pass in times thereafter (and which now are readily apparent), had me married and given in marriage to my dearest lord Charles, duke of Brittany, to defend and keep me and my goods, to my profit: the duchy of Brittany, the succession of which I awaited. Against which succession a number of my adversaries, enemies, and ill-wishers have challenged me, and on this [matter] resist against my right and challenge me in it - and they would have done it and deprived [me], if not for the very great power of my said lord and husband, milord Charles, and of his very great and high lords and friends. ${ }^{33}$

Froissart wrote from a vantage point vastly different from that of Jeanne's charter, but the two texts illustrated the dynamics of Jeanne's position along very similar lines. Within the framework of both accounts, Jeanne was unambiguously the heiress, but Charles also derived authority through her. Despite the persistence of her enemies, the rightfulness of her claim was widely acknowledged. This led to the personal loyalty that Jeanne inspired in her followers: the friends who protected her interests in the text from 1343, and the barons who fought for her in the Chroniques. Jeanne dictated what could and could not be done with the duchy but, thanks to her husband and their knights, was not personally responsible for enacting these decisions.

Rather than implying any direct association between a single document written by a ducal secretary in Brittany and the preeminent contemporary history of the early Hundred Years' War, the resonances between these two passages reflected norms of the wider political world in which both were composed. Conventionality, far from being servile, was essential to the text's ability to communicate a reputation in the face of complex contemporary social standards, by imposing familiar models for the way in which status, position, or actions should be interpreted in a given case. Jesse Mortelmans has discussed how late medieval chroniclers

\footnotetext{
33 'Sachent touz que puis la mort de mon trescher seigneur et pere mons. Guy de Bretaigne fusse jeune demoree et orfeline, mes bons et loiaus amis, consideranz et attendanz les chouses et les caus[es] qui peussent avenire $u$ temps ensuiant, et comme a present appert notoire...me eusent et aient mariee et donnee par mariage a mon treschier seigneur mons. Challes, duc de Bretaigne, pour moy et plus profitablement moy mes biens, le duchie de Bretaigne, la succession du quel je attendoie, garder et deffendre...contre la quelle succession et descendue du dit duchie pluseurs mes adversaires, anemis et malvuillanz mont chalongie...et sur ce resiste contre mon droit, et en le me chalongent e leussent fait et defait, se ne fut la tresgrant puissance de mon dit seigneur e mari mons. Challes et de ses tresgranz et hauz seigneurs et amis', RACF, n. 19. Jeanne's father Guy de Penthièvre died in 1331.
} 
such as Froissart used stylistic elements of administrative and legal rhetoric to structure their narratives and to lend them authority. ${ }^{34}$ This relationship was more than cosmetic: it stemmed from a similar need to make clear statements and extended to the ways in which figures of authority were made to conform to social expectations. Crucially, this codification did not make such a reputation any less legitimate; indeed, contemporary inquiries into an individual's fama actively distilled that which was reported into idealized categories. ${ }^{35}$ Froissart's narrative account was, of course, not formally structured in such a way; nevertheless, there remained this relationship between the conventional and the specific, and it is in these details that Froissart worked and reworked his portrayal of Jeanne. If, in the moments before Auray, Jeanne appeared in a multifaceted position of power, Froissart elsewhere focused on partial aspects of this role: Jeanne as heiress, or lady, or military leader. I will consider each of these in turn to centre the analysis around the salient points of variation between Froissart's different textual redactions. These successive lenses suggest multiple influences on the process of modelling and re-modelling Jeanne's legal claims, political relationships, and decision-making into characteristics of her reputation. Their net effect demonstrates that there was no fixed checklist of features constitutive of the portrayal of public authority; even under the same circumstances, a figure like Jeanne could be plausibly perceived in different ways.

\section{La droite heiresse: A question of legitimacy}

Jeanne's claim to the duchy of Brittany was in a sense her prime qualification for appearing in the chronicle, but Froissart's assessment of her rights and their implications for her role differed in the three versions, none of which exactly mirrored Le Bel. ${ }^{36}$ While Froissart's self-positioning as a neutral reporter meant that he did not overtly favour either side in the Breton conflict, he (like Le Bel before him) gave Jeanne's claim a more solid foundation than Jean de Montfort's by reporting the misunderstanding that Jean was the maternal half-

\footnotetext{
${ }^{34}$ Jesse Mortelmans, "Escrire et mettre par mémoire: La fausse objectivité dans les chroniques en moyen français," in L'écrit et le manuscrit à la fin du moyen âge, ed. Tania van Hemelryck and Céline van Hoorebeeck (Turnhout, 2006), $239-50$.

${ }^{35}$ For instance, the canonization trial of Jeanne's husband Charles, held in 1371, recorded what each witness had to say regarding Charles' chastity, piety, generosity, patience, sense of justice, and so on: Sérent, Monuments.

36 The differences between the redactions can be seen in a very basic way by the numbers. Both Le Bel and Froissart discussed Jeanne's rights when developing the causes of the war (Le Bel, 1:247; Amiens, 2:97; B, 2:87; Rome, 462). But thereafter, Le Bel referred to Jeanne's stake in the duchy or transmission of those interests to Charles only twice. The B manuscripts were similar, with three mentions. Both Amiens and Rome, however, referred much more continuously to Jeanne as 'heritiere' or to Charles as duke 'depar sa femme': the former redaction ten times, and the latter six despite ending in 1350.
} 
brother of Jean III and so unrelated to the line of Brittany. ${ }^{37}$ Unfortunately, this glaring mistake has distracted from the fact that Froissart actually explored the validity of Jeanne's inheritance from a number of other angles. ${ }^{38}$ The first and last redactions went further than the B text in characterizing the different elements that made Jeanne a legitimate heir: birthright, election, and royal confirmation. This grounded her reputation as an heiress in the same arguments that had originally supported her claim to Brittany, standards of legitimacy with legal and social weight. $^{39}$

Just as hereditary right was to become, for the kings of France, the most significant criterion of legitimacy, so too were family ties fundamental to the Breton succession. ${ }^{40}$ The Chroniques claimed that Jeanne's blood right was recognized by her uncle, who saw her as his legitimate successor and feared his half-brother's usurpation. The importance of this relationship influenced how Froissart characterized the nature of the succession crisis, not only in its details but in the structure of his account. Froissart's three main versions of the initial problem are compared in Table 1, alongside Le Bel's original passage. ${ }^{41}$ This highlights the four main points which established Jeanne as heiress of Brittany in all four versions, albeit never in precisely the same way. ${ }^{42}$ Le Bel's account was terse and to the point, mentioning without much elaboration the deceased brother (1), the orphaned daughter married to the French prince (2), the offer of the duchy (3), and the rival claim (4). Froissart's B version adhered exactly

\footnotetext{
37 Stahuljak, "Neutrality"; Jones, "Breton Civil War," 69-70; Le Bel, 1:246; Amiens, 2:97; B, 2:87; Rome, 463. This misconception is perhaps surprising in light of Le Bel's English sympathies, but attests the efficacy of Valois propaganda: Chareyron, Le Bel, 209, and see below, page 29-30; cf. Débat, introduction; Cassard, Guerre, 37-49; Jones, "Breton Civil War," 76-77; Antonia Gransden, "The Alleged Rape by Edward III of the Countess of Salisbury," The English Historical Review 87 (1972): 340-41.

38 The argument that Froissart understood Jean de Montfort to have the greater legitimacy, advanced by Valentina Mazzei, "The Two Claimants and Their Champions: War in Brittany in Words and Images in Book I Manuscripts of Froissart's Chroniques," in Battle and Bloodshed: The Medieval World at War, ed. Keira Borrill and Lorna Bleach (Newcastle-upon-Tyne, 2013), 137-60, overlooks numerous aspects of the chronicle account as well as its historical context (let alone that of the war), and is ultimately unconvincing; she does, however, draw attention to a possible attempt to correct the genealogical error in a certain subset of manuscripts (154, note 10).

${ }^{39}$ Charles T. Wood, Foan of Arc and Richard III: Sex, Saints, and Government in the Middle Ages (Oxford, 1988), 12-28, discusses a similar trio of heredity, election, and coronation in the successions of France and England. On the Breton investiture ceremony at Rennes and their homage to the king of France, see Françoise Féry-Hue, "Le cérémonial du couronnement des ducs de Bretagne au XVe siècle," in Missel Pontifical de Michel Guibé, XVe siècle: Céremonial du couronnement des ducs de Bretagne (Rennes, 2001), 38-39; Paul Jeulin, "L'hommage de la Bretagne en droit et dans les faits," Annales de Bretagne 41.3-4 (1934): 380-473.

40 Wood, Foan of Arc, 20-21.

${ }^{41}$ Le Bel, 247-48; Amiens, 2:97-98; B, 2:87-88; Rome, 462-63.

42 Note that there were further variations in the passages from which these are excerpted - the Rome manuscript, for instance, was the only one to introduce Jeanne by name or mention her non-ducal inheritance- but they always occupied the same narrative position.
} 


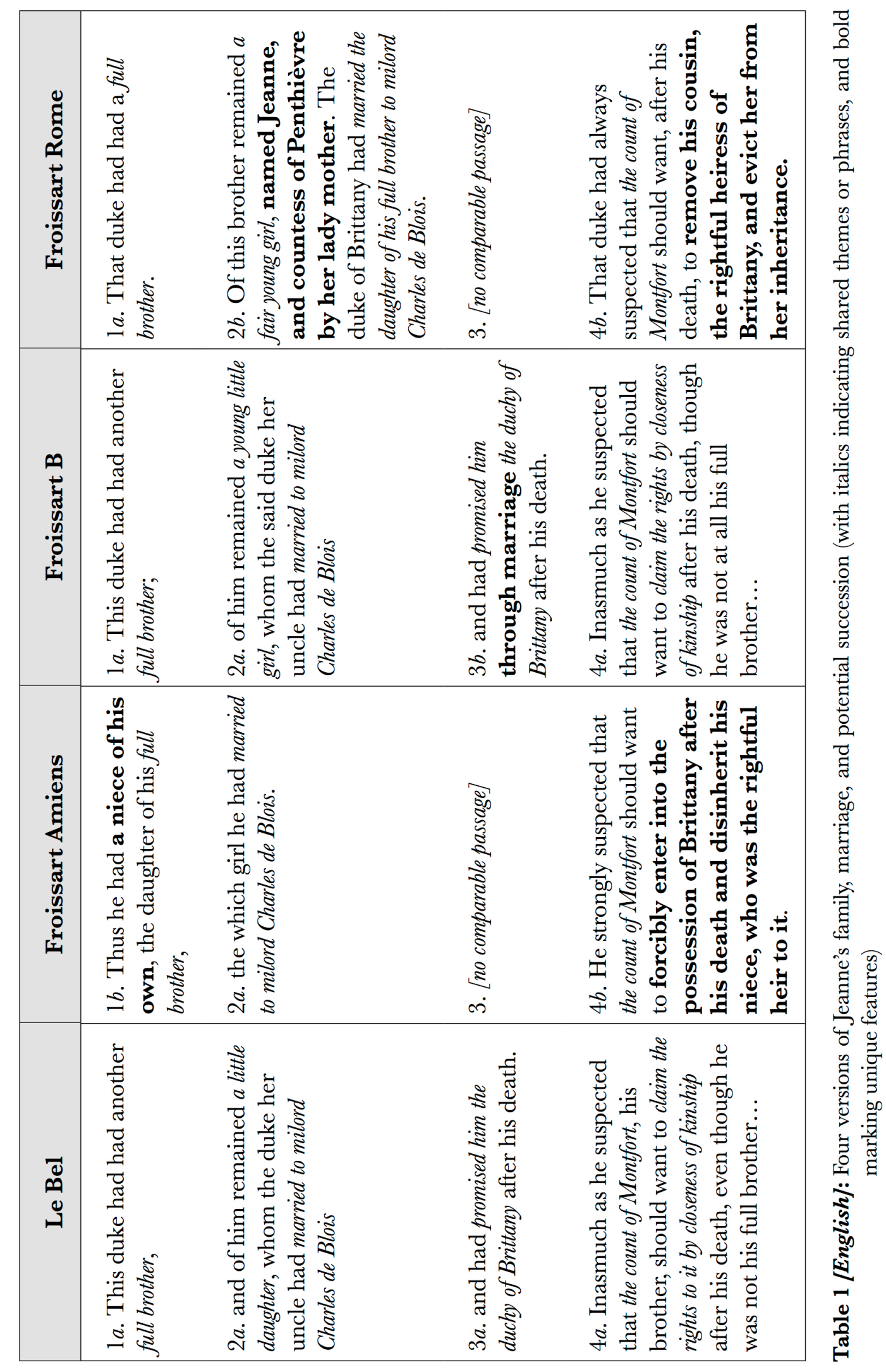




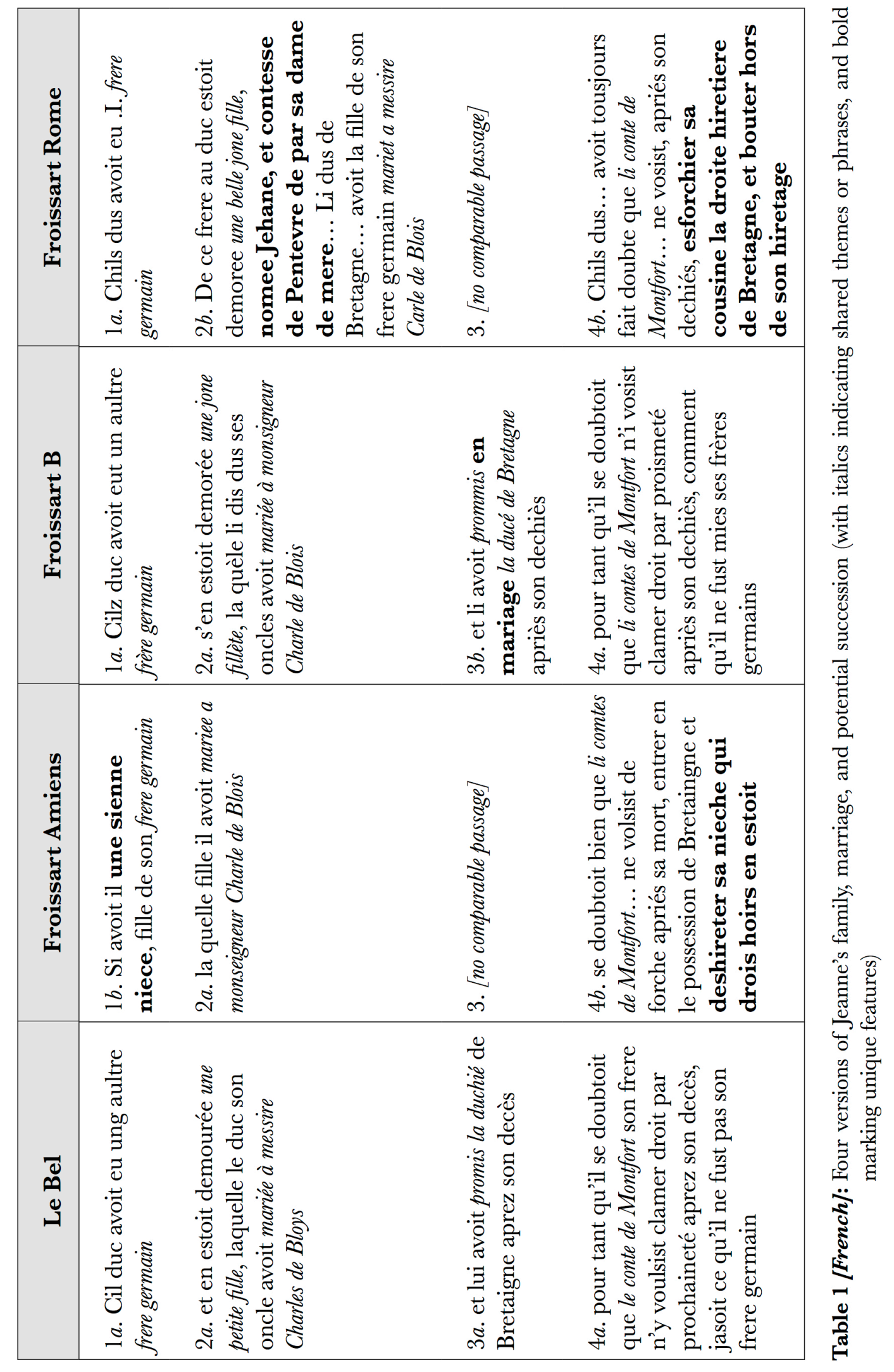


to this flow of information. ${ }^{43} \mathrm{~A}$ slight addition - that Charles received the duchy through marriage - was all that gave more weight to the proxy nature of Charles' inheritance (though it should not be overlooked). ${ }^{4}$ The Amiens redaction, by contrast, altered the sequence of these core facts, and began with Jean III's relationship not to his brother, but to his niece. This emphasized Jeanne's direct ties to Jean and shifted the focus to how she held the claim in her own right, rather than simply transmitting it from her father to her husband. In this vein, both Rome and Amiens omitted item 3, for which 4 substituted: this introduced Jeanne's claim to Brittany not in conjunction with the arrangements for her marriage, but with the discussion of Jean III's fears about his half-brother's coup, and so the succession remained a family matter. ${ }^{45}$ Only then did they return to the topic of Jeanne's union: Charles was there to protect her claim, not promoted for the sake of his marriage. ${ }^{46}$ This kept the emphasis, at the start of the crisis, on Jeanne the heiress rather than Charles the heir.

Closely tied to the issue of inheritance was the recognition of legitimacy by the regional elite. Jeanne's birthright, Froissart suggested in the Rome text, carried weight with the Breton nobles, who saw Jeanne as 'the rightful heiress (droite hiretiere) of Brittany'. ${ }^{47}$ However, he also reported the view that formal recognition by the regional nobility was a distinct, necessary part of confirming the rightful duke. ${ }^{48}$ The Amiens manuscript likewise drew attention to an

\footnotetext{
${ }^{43}$ As did the abridgement, if more briefly (omitting most notably item 3); that it was not a completely servile composition, however, is shown by its unique remark that 'l'avoit ledit duc mariée en son vivant et à grant linage': Abridgement, 105 (cf. 'le plus grandement estoit [Charles] enlinagiez en Franche', Amiens, 2:97).

${ }^{44}$ Of course, there are multiple manuscripts of the B version, and these could themselves vary; for instance, the group of four texts associated with the early fifteenth-century libraire Pierre de Liffol contained something of an amalgamation between item $4 a$ and $4 b$. The source of this variation is unknown, but does attest the importance given to this passage by those who worked with Froissart's text. On this group of manuscripts, see Godfried Croenen, "Pierre de Liffol and the Manuscripts of Froissart's Chronicles," in The Online Froissart, ed. Peter Ainsworth and Godfried Croenen, v. 1.5 (Sheffield, 2013), http://www.hrionline.ac.uk/onlinefroissart/apparatus .jsp?type $=$ intros\&intro=f.intros.GC-Pierre.

${ }_{45}$ The structural similarity of this sequence in the two versions, quite distinct from the B text, helps counter the possibility raised by Palmer, "Book I," 19, 20, 23, that Amiens might result from the modifications of another author.

${ }^{46}$ All four passages ended by stressing Jeanne's rights. Le Bel and the B text stated that Jean thought his niece was 'par raison, plus prochaine d'avoir le duchié aprez son trespas'. The Amiens manuscript followed up item 4 on the chart above by emphasizing again that her marriage was specifically conceived to defend her rights and inheritance (while the Rome passage tended to minimize repetition of this sort in favour of cleaner prose). Having drawn attention (back) to Jeanne, all four texts concluded that the primary benefit of the Blois-Penthièvre marriage was that Charles' French relations would 'mieux et plus volentiers' support Jeanne's succession. This final point does not erase the differing effects of the initial introduction of the actors and their roles, but does demonstrate the different contributions of Jeanne and Charles to their cause: she was their claim to legitimacy, and he the means of enforcing it. See also the 1343 donation cited on page 8, above.

${ }^{47}$ Rome, 464.

48 'Recheus...de tous les barons et fievés ensi conme il apertient a estre recheus', ibid., 468.
} 
occasion on which Jean III asked a thousand Breton knights to swear 'fealment' their recognition of Jeanne's rights. ${ }^{49}$ It almost goes without saying that Le Bel included none of this material. Nor did the B version, until the years in the 1360s which Le Bel did not cover, where Jeanne's speech to the knights before Auray picked up the slack; but it was clearly important to Froissart's conception of Jeanne's legitimacy as heiress in the Amiens and Rome texts. His portrayal of her support among the nobility contrasted sharply with the non-attendance of the great lords when invited to pledge themselves to Jean de Montfort at Nantes in 1341.50

Both inheritance and election reflected arguments actually made by the Penthièvre lawyers in the case for Jeanne and Charles' succession in 1341. They claimed that Jean had ratified Jeanne's natural position as his heir, and that this choice was accepted, at Jean's request, by 'all the barons and the great lords of the region [who] saw clearly that she was and should be the true heiress of Brittany'. ${ }^{51}$ Unsurprisingly, Jeanne and Charles also continued to stress her familial and political ties in their later documents - as, for instance, in the 1343 donation seen above. In her acts, Jeanne varied between presenting herself as the heir of her father Guy and of her uncle Jean, and in the early 1350s she redesigned her personal seal to present more explicitly her several hereditary links. ${ }^{52}$ This demonstrates that Jeanne herself had multiple options in how exactly she chose to emphasize her legitimacy; these variations were not new to Froissart. At the same time, the thematic resonances between her acts and the Chroniques reveal the most essential elements of Jeanne's claim.

Moreover, the prominence of these legally-persuasive demonstrations of Jeanne's right in Froissart's work must be understood in light of his insistence on the importance of the lawful recognition of Jeanne's claim by the king of France. In fact, even Le Bel and the B text noted the influence of the official judgement on reactions to Jean de Montfort's demands in Brittany. According to Froissart, Jean attempted to take rapid military control over the duchy's towns at

\footnotetext{
${ }^{49}$ Amiens, 2:110.

${ }^{50}$ Ibid., 2:101; B, 2:89; Rome, 465-66.

51 'Tous les barons et les gr[a]ndes seigneurs du paï... verrent clairement qu'elle estoit et debvoit estre vroye heritiere de Bretaigne', Débat, II, n. 41. Jean III almost certainly did support his niece's succession by the time he arranged her marriage to Charles in 1337: see below, note 59.

${ }^{52}$ RACF, e.g. n. 8, 17, 19, 22; for a particularly good impression of Jeanne's second seal, see that of Archives départementales de Loire-Atlantique, Nantes, E 165-10 (cf. RACf, n. 310), an image of which is available in their digitized database of seals at https://archives.loire-atlantique.fr/jcms/chercher/archives-numerisees-fr-c_5562. The new seal included, in addition to Jeanne's personal arms, individual heraldic roundels pointing to four of her paternal and maternal ascendants in the past two generations; for a more in-depth discussion of this change and its political circumstances, see Erika Graham-Goering, "Negotiating princely power in late medieval France: Jeanne de Penthièvre, duchess of Brittany (c.1325-1384)" (PhD diss., University of York, 2016), 216-21.
} 
the start of the war, a nigh-impossible chévauchée which provided the backdrop for a good number of dramatic encounters. ${ }^{53}$ Garnier de Clisson, who held Brest in 1341, refused to recognize Jean de Montfort as his lord without formal orders (mandement et enseignes) confirming that his was the better claim. ${ }^{54}$ This sentiment was more thoroughly detailed in the Rome version, where Garnier explained that legitimacy would come only as the result of proper legal procedure, when the case was debated in Paris in the presence of the king and the twelve peers of France. ${ }^{55}$ He stressed too that the new duke must not only be received by his lords, as we saw above, but also by the king in homage. ${ }^{56}$ This linked Jeanne's approval within Brittany to the official practices of France, but also stressed the importance of the legal protocol (which Jean de Montfort flagrantly flaunted).

In fact, Garnier's speech to Jean de Montfort in the Rome text rolled all three components of legitimacy seamlessly into each other. While insisting that the prince receive baronial and royal approbation, he also recalled that

I spent many days and nights alongside milord your brother, and so I heard him say and affirm that you have no right in the duchy of Brittany, but milord Charles de Blois has it through his wife's cause, who was the daughter of milord Jean de Bretagne, count of Penthièvre and full brother of the good duke lately deceased. ${ }^{57}$

The real Jean III's explicit opinions seem to have been rather more ambiguous - both sides agreed in 1341 that the duke had not wished to 'burden his soul' with the issue - but in the chronicle, his support was almost automatically implicated by the powerful trifold argument of blood right/political recognition/legal ratification. ${ }^{58}$

The similarity between the Amiens and Rome texts and the official and legal views of Jeanne's legitimacy was probably due less to Froissart's close study of her particular case than to the shared understanding of what constituted a rightful claim in this period. Nevertheless, the details - that there was an official gathering of barons who formally acknowledged Jeanne's

\footnotetext{
${ }^{53}$ On the invention of this chévauchée and the actual (non-)events of the summer of 1341, see Débat, introduction.

${ }^{54} \mathrm{Le}$ Bel, 250; $B, 2: 91$. The Amiens text and the abridgement both stressed Jeanne's right to the duchy at this point, but without such an emphasis on procedure (in fact, Garnier refused to 'ever' recognize Jean as his lord): Amiens, 2:160; Abridgement, 107.

55 Rome, 469.

56 Ibid., 468.

57 'Je ai esté moult de jours et de nuis dalés monseigneur vostre frere...et se li ai oy dire et affremer, que a la ducee de Bretagne vous n'avés nul droit, mais [l'a] mesires Carles de Blois en l'oqison de madame sa femme qui fille fu a mesire Jehan [sic for Guy] de Bretagne, conte de Pentevre et frere germain au bon duc darrainement mort', ibid., 469.

58 Débat, II, n. 72 (cf. I, n. 123).
} 
claim or that people had asked Jean III for his personal views, for instance - related directly to the situation as it was in Brittany, or at least as Jeanne's party had wanted it to be perceived. Because Froissart's source for these elements was certainly not the Penthièvre succession case (or any of Jeanne's other documents), it is noteworthy that they had entered the more general flow of information surrounding the war, and may in part reflect the public nature of the gatherings which confirmed her succession. ${ }^{59}$ More significant was Froissart's decision to develop the most visible and socially-relevant aspects of her status as an heiress in his accountor to leave them largely unstated, as in the B version. Being an heiress neither guaranteed Jeanne's inclusion as an actor in the rest of the chronicle, nor was its prerequisite; this is consonant with the records left more directly by Jeanne's career, as well as with the observations of other historians concerning the social dynamics of who came to wield seigneurial power. ${ }^{60}$ Jeanne's legitimacy as an heiress should therefore be considered more than simply a premise or structural element of Froissart's narrative of the opening of the War of Succession: it also functioned independently as a dynamic component of her personal reputation in this work.

\section{Leur droite dame: A question of loyalty}

Despite his attention to her personal stake in the Breton inheritance, Froissart referred to Jeanne most often as 'the wife of milord Charles de Blois': it was easiest to define her by her relationship to her husband. However, the counterpoint to this was that Charles was duke 'by virtue of his wife'. Within the Penthièvre faction, Froissart had to account for two potential objects of loyalty, each critical to the cause in a different way. ${ }^{61}$ The Amiens text in particular stressed the devotion of Jeanne's followers during the war; this relationship served, in some ways, as an extension of the 'electoral' element of Jeanne's succession. But it is also significant in its own right in light of recent research on how power was shared by ruling couples, which has shown that in many ways the full princely authority of the couple resided in both partners individually. ${ }^{62}$ Froissart's representation of the allegiance to Jeanne as duchess, however, was specifically different from Charles' relationship with the barons of Brittany; this rhetorical

\footnotetext{
${ }^{59}$ Débat, II, n. 43, 44.

${ }^{60}$ Kimberly A. LoPrete, "Women, Gender and Lordship in France, c.1050-1250," History Compass 5-6 (2007): 1928-29; Sjursen, "Jeannes," 39.

61 'Depar sa femme', or other similar phrases, e.g. Amiens, 2:172, 179, and 3:407; B, 2:102; Rome, 464, 474, 480.

62 For an excellent overview of theories of shared power, see Sjursen, "Jeannes," 6-11, 39, and the detailed study by Elena Woodacre, The Queens Regent of Navarre: Succession, Politics, and Partnership, 1274-1512 (Basingstoke, 2013).
} 
distinction suggests that under some circumstances Jeanne's distinctive status as heiress could be understood in social as well as technical terms and positioned as a core part of her authority.

The Amiens version of an exchange between Jean de Montfort and Henri de Spinefort, captain of Rennes, immediately stressed Henri's devotion to Jeanne as the product of her inheritance. ${ }^{63}$ In response to Jean's demands that he surrender his town in 1341, Henri claimed 'he would never abandon his rightful lady, the wife of milord Charles de Blois, and that he had always held her as the heiress of Brittany. Also all those of the city of Rennes agreed with him'.64 Because he was convinced of her rightful claim, Henri felt that he and the townsmen served Jeanne herself: his relationship was with her rather than her husband. He maintained that his oath to Jean III had been to support Jeanne 'as lady and heiress (hiretiere)'. ${ }^{65}$ At the same time, he even described the legal debate as pitting Jean de Montfort directly against Jeanne, which ran counter to every description of the proceedings in Paris - even those later in the Amiens text, let alone in the actual succession arguments and arrêt of Conflans, where Charles was the central (if not the exclusive) claimant against Jean. ${ }^{66}$ This suggests that the causality of status and relationships could also run the other way: Henri's adherence to Jeanne did not admit Charles as a proxy in the question of the succession, and so the legal issue was recast to reflect this logic.

The Amiens text also implied that this faithfulness was not simply the affair of individual captains and lords, but extended (at least in theory) to the population at large. Jean de Montfort soon captured Henri at Rennes, complicating his claim that all the town's inhabitants shared his Penthièvre loyalty: in fact, the commoners simply wanted Henri himself freed even if this meant surrendering. However, the city's elite refused to 'commit fraud or be disloyal towards their rightful and natural lady on behalf of a single knight'. ${ }^{67}$ This exchange helps clarify the mechanics underlying the ties of loyalty expressed across this passage. Jeanne's legitimacy as

\footnotetext{
${ }^{63}$ Given the historical problems with Froissart's narrative of the early months of the war, the direct factual basis of this scene must be highly dubious: Jones, "Breton Civil War"; Jones, "Ancenis." The captains Henri de Spinefort or d'Espinefort ('de Pennefort' in Froissart's work) and his brother Olivier were from a noble family in southern Brittany.

${ }^{64}$ ' Ja ne relenquiroit sa droite damme la femme à monseigneur Charlon de Blois et la tenoit et avoit tenu toudis à hiretierre de Bretaingne. Ossi tout chil de la chité de Rennez estoient de son accord’, Amiens, 2:107.

65 Ibid., 2:111.

66 Ibid., 2:111, 142; Débat, II, n. 1 and passim; Morice, Preuves, 1:1421-24.

${ }_{67}$ 'La conmunauté volloit que la cité fust rendue et messires Henris de Pennefort delivrez; et li rice homme et grant bourgois y estoient tout contraire et disoient que ja n'avenroit que il feissent fraude ne se desloyautaissent enviers leur droite damme naturelle pour .I. chevalier', Amiens, 2:114-15. The Penthièvre succession case had emphasized the high social rank of their supporters in Brittany, a claim that seems to have been largely accurate: Débat, II, n. 111 (cf. 43, 44).
} 
heiress was translated into service, an automatic correlation that Charles could not so easily claim: the elite citizens cast the breach of loyalty as an offense against Jeanne alone. This portrayal may have in part reflected Froissart's attraction to the theme of knightly service to ladies common in chivalric romance. However, Henri's relationship to Jeanne, and that of the rich men of Rennes, was built not out of sentiment, but out of law, right, and nature: Jeanne was literally (rather than figuratively) their lord.

Froissart's decision to give this prominence to Jeanne's position as duchess may therefore have been connected to the interest he took in her succession in the Amiens text. Her visibility here contrasted with the eventual Montfortist historiography, which focused on the struggle between the two would-be dukes; the earliest, Saint-André's Libvre du bon Fehan (1384), almost entirely elided Jeanne from the narrative, and even writers at a greater remove from the events, like Le Baud, understandably had an interest in burying her claim. ${ }^{68}$ However, this did not mean that Froissart invented Jeanne's position over her followers from whole cloth; among her acts, those which established or rewarded ties of service placed the greatest emphasis on her parity with Charles in such relationships. The only surviving indenture from Jeanne and Charles' reign had Robin de Lanvallay swear to hold the castle of Le Gavre on behalf of 'my dearest and most dread lord and lady' and even simply 'mes seigneurs', my lords. ${ }^{69}$ Likewise, whenever Jeanne and Charles rewarded their followers with lands and money (almost always something they undertook together), the letters explicitly emphasized 'the good and agreeable services put forth to help and advise us in keeping and defending our duchy' and other variations on this theme. ${ }^{70}$ As expected in the model of shared princely authority, the rhetoric of loyalty during the civil war demanded allegiance to both duke and duchess - and on occasion, 'especially (especiaument) we the duchess'. ${ }^{71}$

However, this loyalty was shaped by Jeanne's inheritance in such a way that, for Froissart, 'princely authority' became less generic and more personal. In addition to strongly foregrounding Jeanne over Charles in the debate at Rennes, Froissart stressed these distinct motives for obedience at the end of the first phase of the war, when the fighting had calmed

\footnotetext{
68 Saint-André, Chronique, except 1. 604, 1505; Jean Kerhervé, "La 'Genealogie des roys, ducs et princes de Bretaigne’ de Pierre Le Baud (1486)," in Bretagne et pays celtiques: Langues, histoire, civilisation. Mélanges offerts à la mémoire de Léon Fleuriot, ed. Gwennolé Le Menn and Jean-Yves Le Moing (Rennes, 1992), 519-560.

69 'Mes treschers et tresredoubtez seigneur et dame'; Archives départementales des Pyrenées-Atlantiques, Pau, E 629 (1361).

70 'Les bons et agreables services...mis a nous aider et conseiller a garder et deffendre nostre duchie', RACF, n. 4.

${ }^{71}$ Ibid., n. 17.
} 
sufficiently for Jean, duke of Normandy, to take his leave. Froissart described how, leaving Charles and Jeanne in Nantes, Jean asked the Breton barons 'to be good and loyal towards milord Charles his cousin, and to his wife their lady'. ${ }^{72}$ Jeanne and Charles were both presented as the rightful objects of the barons' loyalty. Their relationship was not, however, identical: Charles was characterized as the cousin of the duke of Normandy, while his wife was the barons' lady. In fact, Charles was repeatedly associated with the French forces that King Philip provided; this assistance was the reason he had been betrothed to Jeanne in the first place. ${ }^{73}$ Unsurprisingly, Froissart often showed Charles acting as duke and receiving his men's homage alone, as had occurred in real life. ${ }^{74}$ But it was especially here that Charles could be defined in relation to his wife, on whom his authority depended. ${ }^{75}$ In the Amiens text, Jeanne had the most direct connection to the Breton barons while Charles represented the might of the French crown - a dynamic strongly reminiscent of the preamble to Jeanne's donation in 1343 where Jeanne's 'good and loyal friends, the prelates, barons, and other nobles of Brittany' secured for her Charles' help and that of 'his very great and high lords and friends' ${ }^{76}$

The particular perspective on Jeanne's authority offered through the reported opinions of those around her represented a significant exploration into the implications of her role as heiress and duchess, though it was not to outlast the Amiens text. Even in the course of a few brief passages, Jeanne and Charles could rhetorically occupy distinct social spaces with their own direct and indirect relationships. The different reputations circulating among these fictionalized partisans meant that Jeanne's status (and Charles') became relative and contextual rather than absolute: as in her own rhetoric, each relationship could flexibly reprioritize her importance. This realistic portrayal suggests that shared princely authority had, so to speak, a contingent form and a general one. It was easy to identify Jeanne's social position with her inheritance and for this privileged place to colour the interpretation of her power (and, correspondingly, her husband's). But this link was not inescapable: Charles could also call directly on the Breton barons to defend his heritage - and Jeanne could command simply by virtue of her status as duchess because, for Froissart, being a good prince entailed having the

\footnotetext{
72 'Que il fuissent bon et loyal enviers monseigneur Carlon son cousin et sa femme leur damme', Amiens, 3:301; cf. 300, for the parallel passage with Jeanne de Flandre and the English.

${ }^{73}$ Ibid., 2:97, and see above, note 48.

${ }^{74}$ Ibid., e.g. 2:142, 144-45; RACF, e.g. n. 18, 79.

75 Amiens, 2:153; cf. page 14, above.

76 'Bons et loiaus amis...prelaz, barons et autres nobles de Bretaigne'; 'ses tresgranz et hauz seigneurs et amis', RACF, n. 19.
} 
support of the political community. ${ }^{77}$ Froissart's inclusion of both perspectives responded especially to the narrative of conflict that shaped his work: if under uncontested circumstances the mechanics of authority could be passed over, his evolving conception of the war directly impacted his views of Jeanne's leadership role, to which we will now turn.

\section{La dame qui s'en est appellée duçoise: A question of action}

After Amiens, Froissart moved away from how others responded to Jeanne and focused more on how she herself made decisions regarding the war. However, he not only increased the frequency with which he showed Jeanne actively influencing events from the Amiens to the $\mathrm{B}$ version, and again from the $\mathrm{B}$ version to Rome, he also changed his characterization of her actions. Particularly after Charles' capture at La Roche-Derrien in 1347, Froissart decided in the $\mathrm{B}$ version to show that Jeanne became responsible for taking over the war effort in a way that realistically captured Jeanne's authority as a wartime administrator, a position that was echoed after the defeat at Auray. With the Rome manuscript, he made a radical departure from historical precedent to re-imagine Jeanne as actually taking the saddle, rallying her warriors, and defending her duchy in Charles' absence. This last shift made narrative sense given the models already available from Froissart's own text and speaks to his evolving understanding of the Breton war, but although the passage retained significant details based on the specifics of Jeanne's role as heiress and mother, it demonstrates clearly the boundaries between political and literary reputations.

Le Bel laconically summarized the years following Charles' capture: Charles 'was sent to England, and remained a long time in prison, then ransomed himself for four times one hundred old écus'. ${ }^{78}$ The Amiens manuscript followed this model, even though it incorporated Jeanne's role in other places, such as an anecdote unique to this version in which Charles, anticipating a siege at Rennes,

took counsel that he would depart and milady his wife also, for they would better attend to their designs, if they held the key to the open spaces than if they should be enclosed therein. So he had his wife brought to Nantes, and he went to Suscinio. ${ }^{79}$

\footnotetext{
77 e.g. B, 6:151; Ainsworth, "Froissardian Perspectives," 66. This view was hardly unique to Froissart.

78 'Fut envoyé ledit messire Charles en Angleterre...et demoura long temps en prison, puis se raenchonna de quatre fois cent escus vielx', Le Bel, 2:149. The actual figure was 700,000 écus (RACF, n. 181); this suggests perhaps that this fifteenth-century text is defective, if (for instance) Le Bel had originally written 'quatre fois cent mille escus vielx', which would at least have been in the right order of magnitude.

79 'Eut conseil qu'il s'empartiroit et madamme sa femme ossi car mieux entendiroient à leurs besoingnes, se il
} 
This passage did not show Jeanne making any military decisions: her husband took counsel and had her sent away. But it treated their 'besoignes' and their tactical advantages as shared concerns, and Charles moved Jeanne not simply to a well-defended place but to one of the Penthièvre power bases, a city which Froissart termed elsewhere 'the head and sovereign city of Brittany' ${ }^{80}$

The B redaction further associated Jeanne with planning the war, using a different scene at Nantes. When Bertrand du Guesclin (d.1380), future constable of France and long one of the major Penthièvre captains, arrived there in 1364, Charles and Jeanne 'received him joyfully and kindly, and were very grateful to him for having come. And they held a meeting there together, [about] how they should act; for there also were the greater part of the barons of Brittany'. ${ }^{81}$ Jeanne now participated in the council on strategy while their army awaited their orders, collaborating with the leading figures of the conflict. Her participation comes as no surprise to the reader because, in this version, Froissart did introduce the reader to Jeanne as a military figure after the disaster of La Roche-Derrien. Despite Charles' capture, all his towns and strongholds held firm 'because milady his wife, who called herself duchess of Brittany, took up the war with great will'. ${ }^{22}$ Having assumed Charles' role as a war leader once, it was reasonable for her to engage with subsequent decisions.

Jeanne's shifting relationship to the war between the Amiens and B versions was also illustrated in the aftermath of the defeat at Auray. In both, Charles V sent his brother Louis d'Anjou (d.1384) to comfort and advise his grieving mother-in-law. ${ }^{83}$ In the Amiens text, Jeanne was distressed because 'she who called herself duchess and heiress of Brittany saw her husband, milord Charles de Blois, dead, and her two sons, Jean and Guy, imprisoned in England', a straightforward assessment of Jeanne's present hardships; the captivity of Jeanne's heirs was of particular significance for the future of her line and the continuation of her claim. ${ }^{84}$ In the $\mathrm{B}$

avoient lez clés de camps que ce que il fuissent là dedens enclos. Si fist sa femme amenner à Nantes et il s'en vint au Suseniot', Amiens, 2:279.

80 'Li chiefs et li souverainne chité de Bretaingne', ibid., 2:98.

81 'Le rechurent liement et doucement, et li sceurent très grant gré de ce qu'il estoit ensi venus. Et eurent là parlemant ensamble, comment il se maintenroient; car ossi y estoit li grigneur partie des barons de Bretagne', $B$, 6:148-49.

82 'Car madame sa femme, qui s'appelloit duçoise de Bretagne, prist la guerre de grant volenté', ibid., 4:43. Jones, "Breton Civil War," 70, incorrectly identifies Jeanne's speech at Auray as the first time Froissart shows her command.

83 Amiens, 3:356; B, 6:173. Louis had married Jeanne and Charles' daughter Marie in 1360.

84 'Celle qui s'appelloit duçoise et hiretierre de Bretaingne...veoit son marit monsigneur Carle de Blois mort et ses II fils emprisonnés en Engleterre, Jehan et Ghui'. 
version, the scene became more dramatic: the entire region was in mourning, and Jeanne (now referred to as Charles' wife rather than by title) 'was so grieved and discouraged by the death of her husband that there was nothing to be added': a much more raw, emotional, and seemingly final state of sorrow. ${ }^{85}$

However, subsequent developments reverse these initial perceptions. Louis promised Jeanne, in the Amiens manuscript, to act for her 'as head (chiés) of the war'. This enthusiastic offer of military support would have made Louis an effective replacement for Charles in bringing French force to bear in Brittany. But when Jeanne 'examined closely all her needs, she saw herself in a hard place indeed. Thus she wept and lamented her friends, and with good reason'. ${ }^{86}$ Rejecting the opportunity to press her cause, Jeanne now lapsed into grief-filled passivity. By contrast, Louis' assistance met with a much more positive response in the B text: 'the lady and the region had [in this] great confidence for a while', until the French king's intervention put an end to the combat. ${ }^{87}$ This Jeanne had the will to carry on just as she had in 1347 - and indeed, Pope Urban V (d.1370) had noted when sending envoys to Jeanne in December 1364 the 'warlike aggressions and stirrings, which render difficult the path of the said peace' ${ }^{88}$ It was only when her king opted instead for reconciliation that the structure on which Jeanne relied fell apart and undermined her ability to wage war.

Correspondingly, there was much greater emphasis in the B manuscript on Jeanne as a force to be reckoned with after Auray. In the Amiens manuscript, the younger Jean de Montfort sought Edward III's approval before conceding to peace talks, which Edward quickly granted. ${ }^{89}$ Having obtained this authorization, peace could simply happen: after all, Jeanne had already decided to do nothing in response to her loss. In the B tradition, however, Edward advised Jean to make peace on the condition that the duchy would remain his and that he recompense Jeanne appropriately. ${ }^{90}$ Here, Jean's hold on the duchy was not yet assured. Moreover, Jeanne was entitled to something in return. Not coincidentally, the phrase 'qui s'en est appellée duçoise' was used twice in these negotiations as a reminder of Jeanne's active pursuit of her title, and it

\footnotetext{
85 'Estoit si desolée et desconfortée de la mort de son mari que riens n’i falloit'.

86 'Examinoit bien touttes ses besoingnes, elle se veoit bien en dur parti. Si ploroit et regretoit ses amis et bien avoit cause', Amiens, 3:356.

87 'En quoi la dame...et li pays eurent un espasse de temps grant fiance', $B, 6: 173$.

88 'Offensionibus et commotionibus bellicosis, que viam dicte pacis difficiliorem redderent', Paul Cacheux and Guillaume Mollat, eds., Lettres secrètes $\mathcal{E}^{2}$ curiales du pape Urbain V (1362-1370) se rapportant à la France (Paris, 19021955), n. 1414.

89 Amiens, 3:361.

${ }^{90} \mathrm{~B}, 6: 179-80$.
} 
would appear much earlier in the narrative in the Rome manuscript. ${ }^{91}$

Unusually, a relatively independent version of this scene appeared in the abridged redaction written between the Amiens and B texts, which underlines the importance of Jeanne's response to Auray in the definition of her leadership role. The scene echoed the Amiens version insofar as Jeanne was again grieving over her dead husband and her imprisoned sons. ${ }^{92}$ However, instead of Charles V sending Louis to see his mother-in-law, it was Jeanne herself who here summoned Louis to Brittany 'to help preserve her inheritance' ${ }^{93}$ This introduced a radically different dynamic to Louis' war leadership: he 'obeyed' Jeanne, rather than taking the initiative himself or acting according to his brother's wishes. ${ }^{94}$ This sharpened the contrast when King Charles finally entered the picture. Though, as in the other two versions, he was upset by the loss at Auray, he appeared in the abridgement only to immediately seek peace. ${ }^{95}$ His reasoning, exceptionally detailed here, incorporated the idea subsequently attributed to Edward III in the B text, that Jeanne should at least be given the financial means to maintain herself. ${ }^{96}$ The responsibility for accepting defeat thus lay, as it would in the B version, with the French rather than with Jeanne. The differences and similarities in this sequence compared with those of the redactions both before and after suggest not only Froissart's deliberate experimentation with the question of Jeanne's agency and influence, but also the numerous possibilities for framing any given answer.

The Rome text, of course, does not take us to the end of the war; but even incomplete, it marked a radical departure from the interpretation in the first three texts of Jeanne's leadership as essentially administrative and organizational. For his final version, Froissart completely re-wrote his description of events after La Roche-Derrien:

The wife of milord Charles de Blois, who was holding herself at Nantes and who called herself duchess of Brittany, took up the bit in her teeth and showed the courage of a man and of a lion, and she kept together all her companions, the knights and squires who were of her faction, and she made the viscount of Rohan and milord Robert de

\footnotetext{
${ }^{91}$ Ibid., 6:178-79; cf. 'duçoise et hirettierre de Bretaingne', Amiens, 3:415; Rome, e.g. 482, 817. Froissart tended not to use the title of duke or duchess outright during this conflict: Jeanne's opponents were usually referred to as the count and countess of Montfort. In practice, Jeanne continued to style herself duchess until her death. 92 Abridgement, 418.

93 'Pour aidier à garder son hiretaige'. In fact, Jeanne seems to have left Brittany for Angers after Auray: Sérent, Monuments, 112, 121.

94 'Obéy à le prière de la dame', Abridgement, 418.

95 'Non par manière de guerre, mès par voie de doulchour', ibid., 419.

96 'Que madame de Bretaigne, la femme à monsigneur Charles de Blois, y euist aulcune pension toute sa vie pour maintenir son estat', ibid.
} 
Beaumanoir captains and overseers of her troops. And when the knights and squires came to her in her service, she showed them two fair sons which she had by milord Charles de Blois her husband, Jean and Guy, and said: 'Here are my children and heirs. If their father has done you well, I and the children will do you even better'. And the said lady rode from town to town and from fortress to fortress, those which held for her, revitalizing and encouraging those whom milord Charles de Blois her husband had put and established there. And the lady waged as good and as strong a war against the countess of Montfort and her people, as before milord Charles de Blois and his people had done. ${ }^{97}$

Thereupon, Charles was shipped off to England as before.

This passage uses tropes introduced above, such as Jeanne's base at Nantes and her selfclaimed title. In some ways, it merely filled in the details which the B version could have implied: appointing captains, rallying support, and promising rewards were all part of military leadership. Yet the very decision to add these concrete elements and turn a single line into a lengthy scene suggests the extent to which Froissart had rethought Jeanne's role. She became active, getting on her horse and touring the country, and interacted with her followers in a new way by personally bolstering their loyalty and their morale. ${ }^{98}$ Whereas before she complemented Charles, she now imitated and even surpassed him. This was perhaps the most significant change. Whereas the B text claimed that 'the towns, the cities, and the fortresses of milord Charles' remained loyal as the result of Jeanne's leadership, now they held firm as her 'partie' alone. ${ }^{99}$ She became equivalent to the knightly lord they had lost and in so doing assumed more masculine characteristics. Never in any of the previous versions had Jeanne had to move beyond her gender to perform her role, which fell within the normal bounds of a noblewoman waging war.

Accordingly, this transformation did not reflect the portrayal of Jeanne's actions in any of the official documents surviving from her rule, which never presented her as the physical leader of her troops. Her authority in martial matters was acknowledged by such eminent

97 'La fenme a messire Carle de Blois, qui se tenoit en Nantes et qui se nonmoit duçoise de Bretagne...prist et requelli le frain aux dens et monstra corage d'onme et de lion, et retint tous ses compagnons, chevaliers et escuiers qui de sa partie estoient, et fist le visconte de Rohem et messire Robert de Biaumanoir, capitainnes et regars de sa chevalerie. Et quant chevaliers et esquiers venoient deviers li en son service, elle lor monstroit deus biaus fils que elle avoit de messire Carle de Blois son mari, Jehan et Gui, et disoit: "Vechi mes enfans et hiretiers. Se lors peres vous a bien fait, je et li enfant vous ferons encores mieuls." Et cevauça li [sic] ditte dame de ville en ville et de forterece en forterece qui pour li se tenoient, en rafresqissant et en rencoragant ceuls que mesires Carles de Blois son mari i avoit mis et establis. Et fist la dame aussi bonne gerre et ausi forte a l'encontre de la contesse de Montfort et de ses gens, comme en devant mesires Carles son mari et ses gens avoient fait', Rome, 817-18.

98 This is a far cry from the automatic but distant devotion of her followers in the Amiens text: see above, page 15 .

${ }_{99} B, 4: 43$, emphasis mine. 
figures as Pope Clement VI (d.1352), who wrote to Jeanne that 'we have happily heard that the affairs of you and of your husband, our dear son the nobleman Charles, duke of Brittany, are prospering' after the successful siege of Quimper in $1344 .{ }^{100}$ In Charles' absence, Jeanne placed the abbey of Sainte-Croix of Guingamp under her safeguard and allowed them to display symbols of 'our lordship (seignorie) of Brittany' to signify this. ${ }^{101}$ In 1348, at the request of 'our townsmen (bourgeois) of our city of Nantes', Jeanne released an ordinance making detailed arrangements for the defence of the town, the collection of taxes, and the protection of its liberties. ${ }^{102}$ But such orders were always accompanied by instructions for her officials to see that they were carried out: Jeanne played no personal, physical role in the pursuit of the war, or at least never claimed to play one.

Were her escapades in the Rome manuscript therefore the result of Froissart's passion for recording great deeds of arms as the so-called 'chronicler of chivalry'? 103 If so, this evolution is striking in light of the relatively marginal place traditionally given to women as the doers of chivalric deeds, rather than as their object. ${ }^{104}$ Katrin Sjursen, among others, has argued that women were not excluded 'from certain spheres of action that modern scholars have falsely deemed "masculine", including military affairs, but the transformation of Jeanne de Penthièvre from a woman taking up the war with 'grant volenté' to one with the heart of a man helps clarify the line separating those types of military activity that could be undertaken within the normal bounds of female activity from those that exceeded it. ${ }^{105}$ Writing for 'his warlike, aristocratic contemporaries', Froissart would have understood that while women were sometimes fighters - Jeanne de Belleville (d.1359), who responded violently to the execution of her husband Olivier III de Clisson in 1343, was a notable recent example from Brittany — such

\footnotetext{
100 'Letanter audivimus...tua et dilecti filii nobilis viri Caroli ducis Britannie viri tui negocia in partibus Britannie prosperari', Eugène Déprez, J. Glénisson, and Guillaume Mollat, eds., Clément VI (1342-1352): Lettres closes, patentes et curiales se rapportant à la France (Paris, 1901-1959), n. 944.

101 'Nostre presente sauve et especial garde'; 'les panonceaux de nostre seignorie de Bretaigne', RACf, n. 116 (1349).

102 Ibid., n. 98.

103 The expression seems to have gained currency thanks to George Gordon Coulton, The Chronicler of European Chivaly (London, 1930), although this reductionist perspective on Froissart's role has since been greatly expanded: see Peter Ainsworth, "Jean Froissart: A Sexcentenary Reappraisal," French Studies 59 (2005): 364-372.

${ }^{104}$ Maurice Keen, Chivalry (New Haven, 1984), 186 and passim.; Ludivine Fest, "La chevalière au Moyen Âge: Entre fantasme et réalité," in Le cheval dans les sociétés antiques et médiévales, ed. Stavros Lazaris (Turnhout, 2012), 106-7; Roberta L. Krueger, "Questions of Gender in Old French Courtly Romance," in The Cambridge Companion to Medieval Romance, ed. Roberta L. Krueger (Cambridge, 2000), 140, 145; Katrin E. Sjursen, "Peaceweavers' Sisters: Medieval Noblewomen as Military Leaders in Northern France, 1000-1337" (PhD thesis, University of California at Santa Barbara, 2010), 10, although she has also demonstrated Froissart's interest in such roles. ${ }^{105}$ Sjursen, "Jeannes," 40.
} 
actions were considered signs of an extreme situation. ${ }^{106}$ That Jeanne was willing to continue the fight was to be expected, but that she did so on horseback was a necessity rather than a choice, however heroically she filled the role. ${ }^{107}$

Rather, Froissart's innovative portrayal was inspired most immediately by his own text, where the display of the 'courage of a man and of a lion' was more usually the province of Jeanne de Flandre, the wife of Jean de Montfort. Jean Le Bel had originally and repeatedly described her in these terms, for he established the countess as central to their side of the conflict: before her husband's capture in 1343 she was repeatedly on hand to advise him and celebrate their victories, while afterwards she led a heroic resistance against the Franco-Breton forces of Charles de Blois, such as personally leading a sortie from Hennebont to set fire to the enemy camp. ${ }^{108}$ Froissart transposed this narrative to all three redactions of Book I: it was clearly a powerful model for him, and it was along these lines that he began to revaluate the character of Jeanne de Penthièvre. More specifically, the Rome version patterned Jeanne de Penthièvre's leadership in 1347 on its own interpretation of Jeanne de Flandre's reaction to the capture and death of Jean de Montfort. Froissart explicitly contrasted the Jeannes at the start of this passage: 'if the countess of Montfort was made joyful, the wife of milord Charles de Blois was greatly angered'. ${ }^{109}$ When Jean had been lost, Jeanne de Flandre also 'took the bit in her teeth' and gathered her 'knights, squires, and those by whom she thought to be loved, aided, and served'. ${ }^{110}$ She displayed her fair son to them and implored their aid, before heading off on a tour of her strongholds to encourage her other partisans. This format and the specific phrasing in Jeanne de Penthièvre's 1347 passage make it clear that the relationship was direct. Rather than becoming any virago whatsoever, Jeanne de Penthièvre became, in this moment, her rival.

This link between the two Jeannes was at the heart of Froissart's progressive militarization of Jeanne de Penthièvre, for it reflected the way in which he understood or wished to narrate this aspect of the conflict. Of course, it was Le Bel who initially drew attention to the

106 Ainsworth, Fabric, 84-85; John Bell Henneman, Olivier de Clisson and Political Society in France Under Charles V and Charles VI (Philadelphia, 1996), 26-27. In fact, Chareyron, Le Bel, 266, suggests that there may have been some specific conflation with the deeds of Jeanne de Belleville (d.1359) in Froissart's account of the other Jeannes.

107 Cf. her role at the end of the war, page 19, above.

108 Le Bel, 1:308-09. Plaine, "Jeanne," 8-9, has plausibly argued that her military exploits, which are not corroborated by even the most favourable Montfortist chronicles except insofar as they derive the account from Froissart (e.g. Bouchart, Croniques, 2:52), were fictional.

109 'Se la contesse de Montfort fu resjoie, la fenme a messire Carle de Blois...fu durement courouchie', Rome, 818. 110 'Prist le frain a dens'; 'chevaliers et esquiers et ceuls dont elle pensoit a estre amee, aidie et servie', ibid., 502. 
war between the two duchesses. As a preface to the famous episode of the 'Combat des Trente' in 1351 , he wrote,

so that you might better understand it, you should know that there were still wars in Brittany between the parties of the two ladies; even though milord Charles de Blois was imprisoned in England, and even though there were truces between the two kings, so the parties of the two ladies fought. ${ }^{11}$

This comes, however, as a bit of a non sequitur after his silence on Jeanne's role in 1347, and it does not seem to have greatly shaped his treatment of any other episode.

For his part, Froissart found this passage worth retaining in both the Amiens and B redactions with nearly identical wordings in both, but he dropped the reference to the royal truce, bringing the focus more sharply to the Breton situation. ${ }^{12}$ More specifically, referencing only Charles' imprisonment underlined the fact that his wife was now isolated in the duchyjust the same situation in which Jeanne de Flandre had found herself a few years before. This parallel increasingly shaped Froissart's interest in the female aspects of the war narrative. While Le Bel and even the Amiens manuscript passed over Charles' capture with little fanfare, by the B version Froissart noted that 'thus came to be the war of these two ladies': he was explaining the genesis of this memorable fight and putting substance behind the development of the narrative. ${ }^{113}$ Moreover, he actively involved Jeanne de Penthièvre alongside Jeanne de Flandre, instead of simply having the 'parties' of the two ladies fight one another. By the Rome text, Froissart expanded Jeanne's role into contexts where it had not previously appeared. In the two-year truce accorded after Edward captured Calais in 1347, 'the two ladies of Brittany, the wife of Charles de Blois and the countess of Montfort, were reserved and exempted from this treaty; and these two ladies upheld the war in Brittany, the one against the other'. ${ }^{114}$ Not only did Jeanne de Penthièvre appear in the royal negotiations and even precede her rival but, in their opposition, they single-handedly kept the war alive.

Froissart's introduction of the war as a whole eventually evolved to accommodate this storyline. He had opened the war through a more masculine lens in both the Amiens and B

\footnotetext{
111 'Affin que vous le puissiez mielx entendre, vous debvez sçavoir que toudis estoient guerres en Bretaigne entre les parties de II dames; combien que messire Charles de Bloys fust emprisonné en Angleterre, et combien que treves fussent entre les II roys, si guerroient les parties des II dames', Le Bel, 2:194. The combat itself was a setpiece skirmish between Franco-Breton and Anglo-Breton forces that had a greater literary than military impact. 112 Amiens, 3:298; B, 4:111.

113 'Ensi fu la guerre de ces deux dames'.

114 'Furent reservet et exeptet en celle trieuve les deus dames de Bretagne, la fenme a mesire Carle de Blois et la contesse de Montfort; et tinrent toutdis ces deus dames en Bretagne la guerre, li une contre l'autre', Rome, 856.
} 
texts by setting up the opposition between the 'reason and right milord Charles de Blois had in the great inheritance of Brittany' and 'the count of Montfort, who acted and sided against him, from which so many confrontations, battles, and other great deeds of arms came about in the said duchy'. ${ }^{115}$ The Rome manuscript, however, spoke much more briefly (if with great emphasis) of 'the matter of the wars of Brittany, which were very great and very intense, and which lasted a very long time, and by which very many ills and acts of violence arose'. ${ }^{116}$ If this sudden shift away from great deeds to grim ones reflected the general 'disillusionment' generally seen in Froissart's last redaction, it also set the stage for the desperate situations which would require two unlikely champions - i.e. women - to take to horse. ${ }^{117}$ And by removing the initial parallel between Charles and Jean, Froissart kept open the question of leadership.

It was then a matter of making 'la fenme a Charles de Blois' live up to the towering reputation of her rival and so become an appropriate opponent - especially since the two were never seen directly face-to-face. The Rome version of Jeanne de Penthièvre's performance in 1347 was the logical conclusion to this process, characterizing it in terms already familiar to the reader and so helping them to understand the war through these two Amazonian counterparts. However, Froissart's Jeanne de Penthièvre in 1347 was not the carbon copy of Le Bel's Jeanne de Flandre in 1343. Froissart adapted the passages to reflect Jeanne de Penthièvre's unique personal status. For instance, Jeanne de Flandre broke down in tears before her assembled knights; she highlighted her place as a 'widowed lady and deprived (orfene) of a husband' and asked for their pity or sympathy. ${ }^{118}$ Jeanne de Penthièvre simply promised that she would reward the lords even more than Charles had done, and then took appropriate action. ${ }^{119}$ Her independent authority allowed her to replace Charles rather than emphasizing her loss (nonetheless real enough), while Jeanne de Flandre's prospects were less assured.

This disparity is also visible in how Froissart portrayed the two Jeannes' respective use

\footnotetext{
115 'Quel cause et droit messires Charles de Blois eut au grant hiretage de Bretagne, et d'autre part li contes de Montfort qui en fist fait et partie contre lui, dont tant de rencontres, de batailles et d'autres grans fais d'armes sont avenu en la ditte ducé', $B, 2: 86$. Amiens, 2:96, is identical until 'dont tant de rencontres...', which it omitted; this angle contrasts sharply with the text's subsequent emphasis on Jeanne's inheritance.

116 'La matere des gerres de Bretagne, qui furent moult grandes et moult fortes, et qui durerent moult longement et par lesquelles moult de mauls et de violenses sourdirent', Rome, 461.

117 Katariina Närä, "Tout ce que il appartenoit a une noble et haulte dame': Representations of Aristocratic Female Characters in Jean Froissart's Chroniques Book IV," in The Medieval Chronicle VI, ed. Erik Kooper (Amsterdam, 2009), 230; Rome, 22.

118 Ibid., 501.

119 Cf. her active interest in rewarding their followers, above, page 16.
} 
of their children. ${ }^{120}$ Jeanne de Flandre showed off her husband's son ('his heir and your lord'), to whom she was something of an ancillary. ${ }^{121}$ On the other hand, Jeanne de Penthièvre had her own heirs, and she and they would ensure the future prospects of the party together - the wordorder reinforcing how she took precedence over her children instead of effacing herself behind them. This dynastic power was one that only she, and not her rival, could personally invoke. This was a change from the earlier versions, where Jeanne de Flandre had basically set the loss of Jean aside as inconsequential, his role easily filled by herself and his young son. ${ }^{122}$ But when Froissart assigned a similar role to Jeanne de Penthièvre, Jeanne de Flandre was suddenly stripped of her position and made to conform to a stricter sense of lineal inheritance.

During her own lifetime, the importance of Jeanne de Penthièvre's role as a mother had been recognized in a letter from Clement VI in 1349: 'with the comfort of your children making up for the absence of your husband', he wrote, 'continue towards them the laudable upbringing as commendably as you are said to have begun it, not allowing anyone to associate with them by whose morals these children could be corrupted or injured'. ${ }^{123}$ While his concern was primarily with the moral development of the children's characters rather than their usefulness to Jeanne as political tools, her ability to control her heirs was obviously critical for the future. In her own documents, Jeanne had emphasized her maternal connections with her son Henri at times when the political situation became particularly contentious, especially during her disagreements with the French monarchy in the late 1370s. ${ }^{124}$ The familial bond was both a means of defending her legitimacy and, since Louis d'Anjou was once again the go-between in this situation, a reminder to Louis himself of her authority as his mother-in-law. In fact, Froissart referred specifically to this relationship in the interview between Louis and Jeanne after Auray, for although Louis was in some sense obliged to comfort her, 'he did it willingly, for he had to wife the daughter of the said lord Charles and of the said lady, whom he called

\footnotetext{
120 Geneviève Costes-Sodigné and Bernard Ribémont, "La mère et l'enfant dans les Chroniques de Jean Froissart," in Les relations de parenté dans le monde médiéval: XIVe Colloque du Centre universitaire d'Etudes et de Recherches médiévales d'Aix (Aix-en-Provence, 1989), 337-349, have likewise called attention to the narrative the power dynamics between other mother-and-son pairs at dramatic points in Froissart. See Adams, Isabeau, chapter 6, for the importance of control of the dauphin during Charles VI's reign.

121 'Son hiretier et vostre signeur', Rome, 501.

122 B, 2:115; cf. Amiens, 2:157; Abridgement, 119-20.

123 'Interim autem viri absentiam natorum solatio recompensans, continua erga eos nutrituram laudabilem quam commendabiliter diceris inchoasse, non permittens erga eos conversari aliquos, quorum iidem nati possent moribus infici sive ledi', Déprez, Glénisson, and Mollat, Clément VI, n. 4271 (1349).

${ }_{124}$ D'Argentré, Histoire, 645; RACF, n. 355, 356, and cf. Paul Hay du Chastelet, Histoire de Bertrand du Guesclin, connestable de France (Paris, 1666), 468.
} 
mother'. ${ }^{125}$ Equally, Jeanne's vulnerability here stemmed not from a lack of resources or support, but from the loss of her heirs - the presence of 'one little son who was called Henry' was simply insufficient, though 'he was all her comfort'. 126 Thus, while the two Jeannes accomplished the same ends, the roles they adopted before their partisans were shaped by their different positions.

That Froissart did not make Jeanne de Penthièvre's role in the rest of the chronicle as prominent as that of her Montfortist counterpart was no doubt partly for structural reasons: all three redactions only treated the first two years of the war in detail, when Jeanne was too young to have contributed as Jeanne de Flandre had done. Froissart was apparently uninterested in revising this layout; after all, Jeanne's unexpected intervention after La Roche-Derrien provided an important narrative response to the earlier events. Moreover, Froissart had few external reasons to further embellish her role: if the exploits of the countess of Montfort (though equally fictionalized) were authenticated by Le Bel's account, what we know of Jeanne de Penthièvre's career makes it unlikely that there were any rumours of her personal prowess for Froissart to have heard. But the already-present model of a familiar narrative type could have easily inspired the elaboration of a new, parallel passage at a key moment in the story, especially given Froissart's increased concern for literary coherence in this final version. ${ }^{127}$ While only partial, Froissart's tendency towards assimilating the one Jeanne to the other without erasing the distinctions between them was an effective tool for giving weight to the 'guerre des deux dames' and this theme, exceptionally, demonstrates a reasonably direct evolution across the three main redactions as they are now thought to have been written.

\section{Constructing Jeanne's reputation: Between facts and fictions}

On the whole, though, Froissart reinvented Jeanne from one version to the next (or even within each text) rather than following a progressive narrative line. Comparison between Jeanne's story in each redaction demonstrates precisely the issues of composition and interpretation that previous scholarship has highlighted: Froissart aimed neither at internal consistency nor at 'improving' the previous account when he revisited it. The Amiens version explored, from 1341-43, Jeanne's importance as an heiress and as the initial focus of her

\footnotetext{
125 'Quoique volentiers le fesist, car il avoit à espeuse la fille dou dit monsigneur Charle et de la ditte dame...que il clamoit mère', $B, 6: 173$.

126 '.I. petit fil qui estoit appelés Henris'; 'c'estoit tout ses recomfors', Amiens, 3:356.

127 Michaël Schwarze, "Froissart sous l'empreinte du pouvour," in Froissart à la cour de Béarn: L'écrivain, les arts et le pouvoir, ed. Valérie Fasseur (Brepols 2009), 74; Jones, "Breton Civil War," 71-72; Rome, 23-24.
} 
supporters' loyalty; thereafter, however, the theme was more-or-less abandoned as Jeanne vanished from the stage, reappearing only to deliver an inspiring speech before Auray - the first time she had appeared as an actor in this narrative. The B version 'reverted' to Le Bel for the record of the war's early years. ${ }^{128}$ However, Froissart gave greater thought to the parallel suggested by the 'guerre des deux dames' and began to make this theme more evident after 1347, even if he stripped down the explicit recognition of Jeanne's authority. Finally, the Rome manuscript reinstated (so to speak) some of the initial emphasis on Jeanne's inheritance, but did not detail the early devotion to her cause as in the first version; this was more than offset by Jeanne's active role after 1347, but this comes as more of a surprise for being so explosive. It was the $\mathrm{B}$ version that circulated most widely in the medieval period; but should the slightly earlier and more freely-composed Amiens manuscript be taken to reflect more closely how Jeanne's place in the war was seen in the years surrounding her death? ${ }^{129}$ Were the changes in the Rome text simply literary invention, enabled by the increasing chronological distance from the events described? Such questions do not meaningfully reflect the nature of this source: across all three redactions, Froissart operated in the space between specific historical detail and generalized social framework.

Indeed, that there were multiple coexisting angles taken on her role, and that these had a complex relationship with the wider political discourse, are central to understanding this text as an arbiter of Jeanne's reputation. To reinterpret was not necessarily to make more or less accurate, nor did consistency across the different texts imply a more convincing or correct report. To illustrate this, consider Froissart's treatment of technical details such as the legal arguments that shaped Jeanne's life. In his discussion of the arrêt of Conflans that had awarded Brittany to Jeanne and Charles at the start of the war, Froissart claimed that the king's judgement rested on two key points: one, that Jeanne was the closer heir, and two, that Jean de Montfort had defied Philip's orders to remain in Paris and had sworn homage to Edward. ${ }^{130}$ Froissart was not drawing on the one piece of definitive evidence available in this case, namely the arrêt itself (nor was it his habit to rely on this type of official text). ${ }^{131}$ As a matter of fact, the

\footnotetext{
128 This is somewhat counterintuitive given that it was in the Amiens text that his introduction to the 'guerres de Bretaigne' praised the work of Le Bel, a reference dropped in both the $\mathrm{B}$ and Rome redactions: Amiens, 2:96; $B$, 2:86; Rome, 461.

${ }^{129}$ Unfortunately, little is known of the early ownership of either the Amiens or Rome manuscripts: Amiens, 1:vvi; Rome, 18-19.

130 Amiens, 2:142; B, 2:106; Rome, 489-90.

131 Tucoo-Chala, "Midi Pyrenéen," 124; Jones, "Breton Civil War," 72-73; but cf. Diller, "Patrons," 152.
} 
royal sentence did not detail the logic of the decision. ${ }^{132}$ It did summarize the cases of the two candidates, though, and with greater accuracy than the largely spurious family tree which Le Bel and Froissart had constructed for the descendants of Duke Arthur II (r. 1305-12). This raises the issue of Froissart's relationship, and therefore that of his audience, with the formal facts of the matter. Either the specifics of the Breton succession did not circulate in Froissart's circlesunlikely, given his close connections with Charles' nephew Guy-or this clarification did not, for him, override the authority of Le Bel. ${ }^{133}$

So how might this passage have been interpreted by readers? If the case had been wellknown at the time, this did not mean the details were so common forty or more years after. ${ }^{134}$ But the ongoing challenges to Jean IV's control in Brittany, the return of Jean de BloisPenthièvre from England in 1387, and of course the inheritance clause in the treaty of Guérande which threatened the new dynasty's stability until the birth of the future Jean $\mathrm{V}$ in 1389, would have all helped keep the original debate relevant. ${ }^{135}$ Moreover, the testimony of the witnesses in 1341 had certainly attested an ingrained talent for the recollection of genealogy, and royal texts such as the Songe $d u$ Vergier had much more recently revisited the issue. ${ }^{136}$ Many of Froissart's readers, especially the Montfortist partisans, must therefore have been fully aware of the invented nature of this account, though of course Froissart's own popularity would have empowered the spurious genealogy. ${ }^{137}$

His presentation of the 1365 treaty of Guérande suggests a very different transmission. Both redactions that extended to the end of the war outlined this agreement, if in a somewhat piecemeal fashion. According to the Amiens text,

the wife of milord Charles de Blois left and came to Paris and had, by the peace arrangements, around twenty thousand florins per year well-allocated in Brittany, a county and land which is called 'of Penthièvre'. And the count of Montfort was required to make great efforts for the deliverance of his cousins, the children of milord Charles

\footnotetext{
132 Morice, Preuves, 1:1424.

133 Tucoo-Chala, "Midi Pyrenéen," 126, has shown that Froissart was generally uninterested in verifying the veracity of reports he received. Valois propaganda had been Le Bel's source, though their stance had of course changed in the 1370s: Jones, "Breton Civil War," 74; cf. Cassard, Guerre, 38.

134 Note, for instance, that 220 witnesses were involved with the Breton succession trial, compared to only 55 for the similarly (in)famous dispute over the county of Artois earlier in the fourteenth century: ibid., 24.

${ }^{135}$ Michael Jones, Ducal Brittany 1364-1399: Relations with England and France During the Reign of Duke John IV (Oxford, 1970).

136 Bibliothèque nationale de France, Paris, MS fr. 22338, f. 166-181v; [?Évrart de Trémaugon], Somnium Viridarii, ed. Marion Schnerb-Lièvre (Paris, 1993), 1:293-305; [?Jean Le Fèvre], Le Songe du Vergier, ed. Marion SchnerbLièvre (Paris, 1982), 1:258-68.

137 Cassard, Guerre, 39.
} 
de Blois, who were prisoners in England. And, if the count of Montfort, named duke of Brittany, should die without having an heir of faithful marriage, the duchy should return to the heirs of milord Charles de Blois. ${ }^{138}$

The $\mathrm{B}$ version altered this core of information very little, aside from transmuting florins to francs. ${ }^{139}$ Both redactions therefore summarized Guérande's main points with a good deal more precision than they had the arrêt of 1341, even if there remained some obvious errors. ${ }^{140}$ Jeanne was to be financially compensated for relinquishing her claims and receive Jean IV's help in liberating her children, who were to be his heirs if he should fail to produce his own: these were indeed the means by which Jean became duke of Brittany, and Froissart did not have to consult the treaty to know them. By contrast, there was one perhaps surprising omission, for he failed to mention the clause excluding women from the succession if a male heir was available. Did he consider this arrangement unimportant, or did it escape his notice?141

These two examples suggest Froissart did sometimes report the 'common knowledge' version of events, but that he could also contradict or embellish information known to important portions of French political society, and that he may have done so deliberately. Despite its immense influence on later traditions, therefore, this chronicle did not represent the be-all and end-all of Jeanne's early posthumous reputation. There was much that Froissart did not discuss, and his process of picking and choosing was not passive, dictated solely by the availability of (mis)information or a single understanding of his material. This diversity is all the more significant given that most other early chronicles in Brittany and in France did not bother to develop Jeanne at all; for Froissart she represented not only someone worth including in his work, but someone whose story he revisited and refreshed in the scope of his larger project.

It would be hazardous, of course, to offer a definitive argument for the motivations behind Froissart's revisions of Jeanne's role. The duchess' own acta had to delineate her authority in order to legitimize her decisions. Changing circumstances - the reasons for a

\footnotetext{
138 'S'emparti la femme monsigneur Carle de Blois et vint à Paris et eut, par l'ordounnanche de le pais environ .XX.⿳一由 florins bien assignés par an en Bretaingne, une comté et terre c'on dist de Pentevre. Et dubt...li comtez de Montfort mettre grant painne à le delivrance de ses cousins, les enfans monsigneur Carle de Blois, qui estoient prisonnier en Engleterre. Et, se li comtes de Montfort nonmés dus de Bretaingne moroit sans avoir hoir de loyal mariaige, la duché devoit retourner as hoirs monsigneur Carlon de Blois', Amiens, 3:361-62.

${ }^{139} \mathrm{~B}, 6: 180-81$. The abridgement presented the information about Jeanne's children first, but covered the same details: Abridgement, 421.

${ }^{140}$ Cf. Morice, Preuves, 1:1590-94.

141 The later redactions were written after this clause became - temporarily -irrelevant thanks to the birth of Jean's son; the Amiens account, however, was very likely completed during the period precisely where the lack of a male heir was quite pressing for the fledgling Montfortist dynasty.
} 
certain gift, a point of political contention, and so on - helped dictate the particular depiction of that authority in each document. Froissart's chronicle, however, had no position to defend; not even the patronage of Guy de Blois in the 1370s caused him to take a pro-Penthièvre stance, and he wrote after the political situation in Brittany had largely stabilized. ${ }^{142}$ As we saw, the gradual narrative development of the 'guerre des deux dames' influenced Froissart's portrayal of certain aspects of Jeanne's role- but not all of them. Rather than proceed on uncertain grounds, I would suggest an alternative perspective: in light of the substantial revisions which Froissart made across the board in each redaction, it is simply not surprising that he took advantage of the multiple possibilities for interpreting the same role. He saw his work as didactic as well as historiographical: he was interested in 'li biens fais des bons', the praiseworthy acts of the good, which were to serve as a model for his male and female readers. ${ }^{143}$ As an exemplar, the prince who 'agit toujours pour la défense légitime d'une terre' would have strongly appealed to noble readers conscious of their own prerogatives and who 'se sont reconnus dans le portrait qu[e Froissart] leur présentait d'eux-mêmes'. ${ }^{144}$ The reputation constructed in the chronicle, like that in Jeanne's acts, was thus one which aimed to conform to, rather than subvert, the wider noble ethos for which Froissart (and the ducal secretaries) wrote; but so long as this ideal was on display - through Jeanne's position as heiress, in the loyalty she garnered, or in her leadership - conformity did not demand uniformity. The plurality of positive types for princely behaviour in an (equally idealized) political situation freed Froissart as to which details helped realize this status; all these Jeannes, in the Amiens, abridged, B, and Rome redactions alike, belonged to the same social world.

To be sure, part of what made it so easy for Froissart to reinvent Jeanne was that, in the grand scheme of the Chroniques, she was not a major player. But even on such a small scale, Froissart was engaging with a rich diversity of ideas: this constitutes both the challenge and the reward of working with this source. All too often, the values emphasized by these texts have been used in modern scholarship to describe the dynamics of Jeanne's career (or those of other

\footnotetext{
${ }^{142}$ Jones, "Breton Civil War," 70. More recently (Jones, "Ancenis," 3), he has instead argued that because of this patronage 'successive recensions of the Chroniques...become increasingly favourable to Charles de Blois or put greater emphasis on the role of his supporters', but his original argument is more persuasive both in light of the narrative content of the Chroniques and because Froissart's association with Guy predated all three redactions (cf. above, note 29).

${ }_{143}$ B, 1.2:2-3; cf. Amiens, 1:1, and Rome, 35, 36. While he did attribute some misdeeds to his various noble characters and, in later books, used them for political commentary, his outlook in Book I was fundamentally a positive one: Diller, Attitudes, 51-54; Närä, "Representations," 229-45.

${ }_{144}$ Diller, Attitudes, 55, cf. 52; Ainsworth, Fabric, 84-85; Jacqueline Picoche, Le vocabulaire psychologique dans les Chroniques de Froissart (Paris, 1976), 9.
} 
women like her) without recognizing that no version offered Froissart's definitive take on Jeanne's reputation, or more fully expressed the role which she had claimed to fulfill. As the present case study has emphasized, Froissart's Chroniques do not represent the expectations of French aristocratic society in some crystallized form, but took active part in a broader discourse that incorporated diverse expressions of lordly power current in the late Middle Ages. 